\title{
Central Bank Governance: A Survey of Boards and Management
}

Tonny Lybek and JoAnne Morris 


\title{
IMF Working Paper
}

Monetary and Financial Systems Department

\section{Central Bank Governance: A Survey of Boards and Management}

\author{
Prepared by Tonny Lybek and JoAnne Morris ${ }^{1}$ \\ Authorized for distribution by Arne B. Petersen
}

December 2004

\begin{abstract}

\section{This Working Paper should not be reported as representing the views of the IMF.} The views expressed in this Working Paper are those of the author(s) and do not necessarily represent those of the IMF or IMF policy. Working Papers describe research in progress by the author(s) and are published to elicit comments and to further debate.
\end{abstract}

This paper identifies issues to consider when designing the structure, size, and composition of the governing boards and management of a central bank. While central bank autonomy and accountability are generally accepted as good practice, there is less consensus regarding the structure, size, and composition of the governing bodies. This paper surveys 101 central bank laws covering 113 countries and classifies the governance structure according to degree of autonomy, functions performed, size, composition, appointment procedures, and terms of the members. The paper concludes that an appropriate balance must be struck between the functions of the governing entities, simplicity, and country specific factors. The functions of the various bodies follow logically if a greater appreciation exists for the type of autonomy delegated to the central bank.

JEL Classification Numbers: E42, E52, E58, N20

Keywords: Central bank independence, central bank accountability, central bank governance

Author(s) E-Mail Address: tlybek@imf.org and jomova@earthlink.net

\footnotetext{
${ }^{1}$ Tonny Lybek is a senior economist in the Monetary and Financial Systems Department of the IMF and JoAnne Morris is a consultant. The authors would like to thank Zsofia Arvai, Marie Therese Camilleri, Thanos Catsambas, Martin Cihak, Sean R. Craig, Jennifer Elliott, Hervé Ferhani, John H. Green, George Iden, Luis Ignacio H. Jácome, Claudia S. Jadrijevic Zenteno, Emmanuel van der Mensbrugghe, Guy Meredith, Arne B. Petersen, Richard Pratt, Marc Quintyn, Marko Škreb, Robert Sparve, Peter Stella, Christine Maria Steven, Mark Stone, Kenneth Sullivan, Anita Tuladhar, and Jan Willem van der Vossen for their comments on a previous draft. Any errors remain the responsibility of the authors.
} 


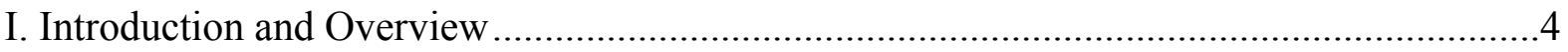

II. Analytical Framework for Determining the Degree of Autonomy ............................... 9

A. Different Types of Central Bank Autonomy..................................................

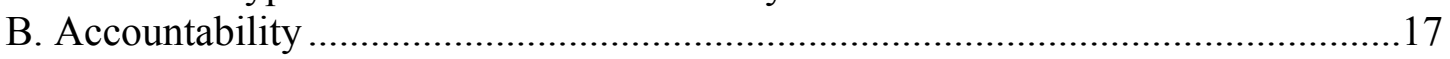

C. Changing Functions of Governing Bodies .................................................... 19

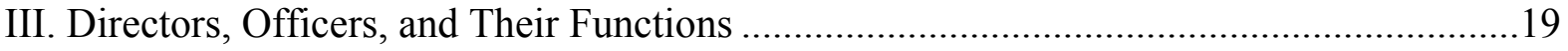

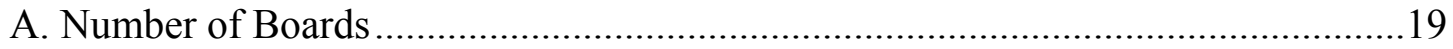

B. Functions of Governing Boards and Management................................................20

C. Boards Performing Several Functions.............................................................24

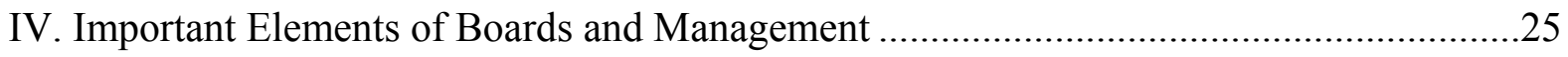

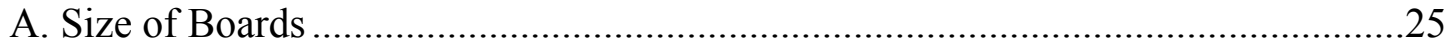

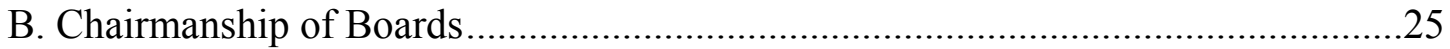

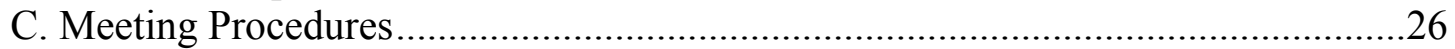

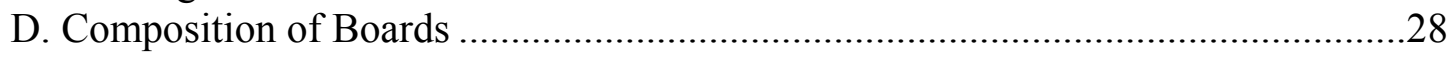

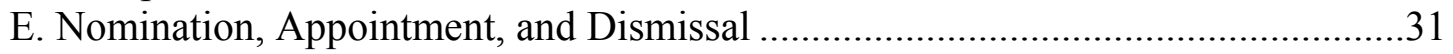

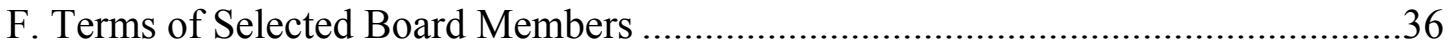

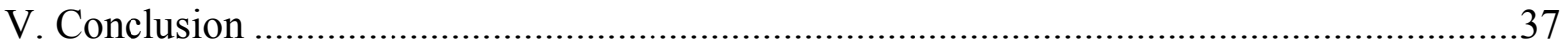

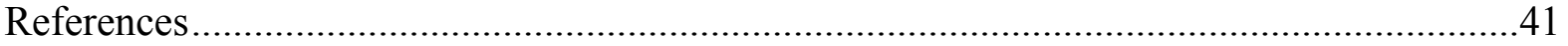

Tables

1. Type of Autonomy in Selected Central Bank Laws, end-2003 ..................................15

2. Authority over Exchange Rate Policy, end-2003 .................................................. 16

3. Type of Autonomy and Accountability for Monetary Policy, end-2003 .......................18

4. Type of Autonomy and Structure of Governing Bodies, end-2003 .............................22

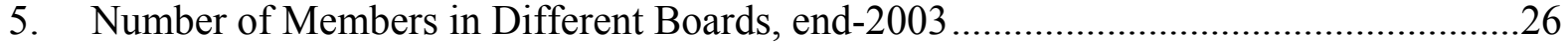

6. Composition of Different Governing Bodies, end-2003 .........................................29

7. Nomination and Appointment of Central Bank Governors, end-2003 .........................33

8. Nomination and Appointment of Non-ex officio Board Members, end-2003................34

9. Terms of Different Central Bank Boards of Non-ex officio Members, end-2003 ..........36

Figures

1. Factors in Designing a Consistent Governance Structure............................................13

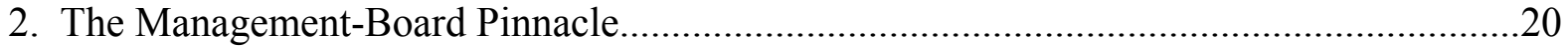

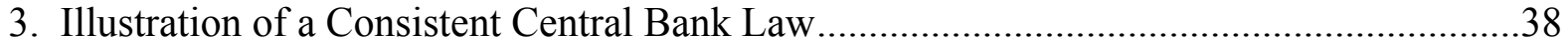


Boxes

1. Empirical Evidence of Central Bank Autonomy and Accountability.....................................5

2. Premises for Central Bank Autonomy and Accountability...............................................10

3. Selected Country-Specific Factors Affecting the Central Bank Governance Structure ......12

4. The Changing Governing Bodies of the Bank of England .................................................21

\section{Appendices}

I. Main Guidelines on Central Bank Autonomy and Accountability .48

II. Central Bank Laws Covered in the Survey..... 


\section{INTRODUCTION AND OVERVIEW}

This paper identifies issues to consider when designing the structure, size, and composition of the boards and management of a central bank. Central bank autonomy and accountability are now generally accepted as good practice. ${ }^{2}$ There is, however, less consensus regarding the structure of the governing bodies of central banks. This is in part due to country-specific conditions and in part because there are many ways to achieve the same objective. In all instances, certain fundamental issues must be addressed. Among these are acceptance of the premises supporting central bank autonomy and identification of the degree of autonomy to be delegated to the central bank, whereupon the functions to be performed by the governing bodies follow logically. The end result may be a comprehensive governance structure with a separate body performing each function, or, in the interest of simplicity, a single board with overlapping functions. If one board serves several functions, it becomes more complicated to determine its composition.

Central bank autonomy and accountability are now generally accepted as the best way to achieve and maintain price stability, which is conducive to sustainable real growth. ${ }^{3}$ Both credibility and flexibility can be achieved by delegating authority over monetary policy to an autonomous central bank with clearly defined objectives and sufficient authority to achieve those objectives and tasks, while at the same time remaining accountable to the government to ensure checks and balances. Although the premises for central bank autonomy are not always fully acknowledged within a country, and empirical studies are supportive but not compelling (Box 1), autonomy has generally prevailed.

Central bank autonomy implies that the central bank is able to resist undue influences from government, industry, and other interests. The design of the board(s) and management should help depoliticize the decision making process (Romer and Romer, 1997). In addition, specified conflict resolution procedures between the central bank and the government should provide a transparent mechanism for attributing responsibility for decisions. A central bank should have sufficient authority to achieve its objectives and to control its own balance sheet. Autonomy also implies, among other things, prohibiting, or at a minimum strictly limiting, direct central bank credit to the government. Furthermore, the central bank's financial condition should not adversely affect its authority. Finally, there must be transparent reporting and accountability procedures in place. These elements provide the general public with assurances that monetary policy and financial system policies are not manipulated. These practices are summarized in Appendix I and discussed in Lybek (1998).

\footnotetext{
${ }^{2}$ In the literature, autonomy is sometimes preferred to the frequently used term independence, as autonomy entails operational freedom, while independence indicates a lack of institutional constraints. Even "independent" central banks typically have strong commitments either to pursue price stability or to follow a specific exchange rate policy, or to comply with a target explicitly stipulated by the government. This paper will therefore use the term "autonomy."

3 See for instance, Cukierman (2002, 1994, and 1992), Berger, de Haan, and Eijfinger (2000), Blinder (1998), Lybek (1998), Fischer (1995a and 1995b) for a discussion of central bank autonomy.
} 


\title{
Box 1. Empirical Evidence of Central Bank Autonomy and Accountability
}

\begin{abstract}
Empirical studies for central bank autonomy are generally supportive but not compelling. Most studies compare an index of the central bank's de jure autonomy — sometimes also accountability_with inflation performance. The design of the index, the elements considered, their weights, and normalization procedures, all affect the results (Mangano, 1998). Another type of study also tries to find such a correlation, but takes other factors into account as well. A third type of study identifies proxies for de facto autonomy and compares them to inflation performance. However, these proxies are often questionable. For instance, a low turnover rate of central bank governors may indeed be caused by strong autonomy, but it may also be caused by governors willing to accommodate government instructions (de Haan and Kooi, 2000). Finally, a few studies estimate whether inflation performance or changes of interest rates after amendments of the legislative framework are significant. While a correlation may be identified, verifying the causality remains a challenge. The question is whether sound economic policies lead to price stability and central bank autonomy, or whether central bank autonomy and accountability result in price stability and promote sound economic policies, or both.
\end{abstract}

Several studies have shown that the industrialized countries that accorded greater legal autonomy to their central banks also experienced lower average inflation during the period following the breakdown of the Bretton Woods system of fixed par values in the early 1970s (Berger, de Haan, and Eijfinger, 2000 and Grilli, Masciandaro, and Tabellini, 1991). Evidence from these countries further strengthened the case for central bank autonomy because the higher degree of autonomy did not appear to harm average real growth (Alesina and Summers, 1993), although a discussion of sacrifice ratios has later emerged (Cukierman, 2002). In recent years, there has been a general commitment to combat inflation, and it has thus become increasingly difficult to identify a correlation between more autonomy and accountability on the one hand and lower inflation on the other. Daunfeldt and de Luna (2003), for instance, find that the decline in inflation often has happened before reforms of the legislative framework. Spiegel (1998), however, found that the announcement of the new legislative framework for the Bank of England in 1997 did coincide with a decline in the interest rate.

Empirical studies indicate that the correlation between legal autonomy and lower inflation in developing countries is less significant (e.g., Cukierman, 1994 and 1992). However, if a pegged exchange rate is used as nominal anchor, it may temporarily alleviate inadequate autonomy (Anyadike-Danes, 1995). Furthermore, the size of the budget deficit and its financing tend to dominate the standard measures of central bank independence (Fry, 1998). Schuler (1996) finds, based on a survey of 156 countries analyzing the period 195293 that central banks in developing countries have performed worse than central banks in developed countries. Gutiérrez (2003) applied an index covering both autonomy and accountability to the constitutions of Latin American and Caribbean countries, taking several factors into account, and does find a significant relationship between a higher degree of autonomy and accountability in the constitution and better inflation performance. Jácome and Vázquez (forthcoming), find, after controlling for the exchange rate regime and fiscal deficits, a negative correlation between more legal central bank autonomy and better inflation performance in Latin American and Caribbean countries.

Some studies have found the correlation between stronger central bank autonomy and better inflation performance in transition economies, among others, Cukierman, Miller, and Neyapti (2001), Maliszewski (2000), Lybek (1999), and Loungani and Sheets (1997).

To insulate the members of the governing boards (directors), management (including governor, deputy governors, and general managers), and members of committees, if any, from undue influence and conflicts of interest, central bank laws frequently mandate qualification requirements, terms for members longer than that of the body with the predominant influence in appointing the member, protection against changing compensation to a member's disadvantage during the term, and protection against arbitrary dismissal. Some laws require that one arm of the government nominate and another appoint key members of 
the governing bodies (double-veto arrangement). At the same time, some coordination with the government as well as accountability and oversight must be ensured. For instance, dismissal in case of gross misconduct should be allowed.

During the last two decades, inflation has stabilized at low levels in most countries, and the focus of the general public has changed toward accountability and transparency. Alleged infringements by directors and officers in a few countries have also advanced this trend. In 1999, the IMF Code of Good Practices on Transparency in Monetary and Financial Policies was adopted. ${ }^{4}$ In March 2000, the IMF adopted the Safeguards Policy primarily to address misreporting and potential misuse of IMF resources. ${ }^{5}$ While the literature on accountability and transparency has grown - for instance, de Haan, Amtenbrink, and Waller (2004); Zilioli (2003); Chortareas, Stasavage, and Sterne (2002); and Cecchetti and Krause (2002) - the literature on central bank governance is, with a few exceptions such as Schiffman (2004) remarkably limited.

Lessons from corporate governance for commercial enterprises, which are country specific, can be useful for central banks. In 1999, the OECD Principles of Corporate Governance were issued and have just been revised. The OECD (1999, page 11) notes that corporate governance “... involves a set of relationships between a company's management, its board, its shareholders and other stakeholders. Corporate governance also provides the structure through which the objectives of the company are set, and the means of attaining those objectives and monitoring performance are determined." This definition implies that a good governance structure ensures that the objectives and tasks delegated to an institution are performed effectively and efficiently, thus avoiding misuse of resources. The Basel Committee on Banking Supervision issued the same year Enhancing Corporate Governance for Banking Organizations to supplement the OECD principles with regard to commercial banks. ${ }^{6}$ Macey and O'Hara (2003) argue that commercial banks, due to their special functions and their impact on the economy, should be held to a higher corporate governance standard that emphasizes their fiduciary responsibilities compared to other enterprises. This approach can be extended one step further for central banks, due to the implications of their actions.

\footnotetext{
${ }^{4}$ For a copy of the code, see: www.imf.org/external/np/mae/mft/code/index.htm.

${ }^{5}$ A Safeguards Assessment reviews the so-called ELRIC areas covering: External audit mechanism; Legal structure and independence of the central bank; financial Reporting; Internal audit mechanism; and system of internal Controls. These assessments stress the importance of sound governance framework, including the board's role as overseeing the financial condition of the central bank, occasionally by recommending establishment of an audit committee. For details, see: www.imf.org/external/np/sec/pn/2000/pn0028.htm.

6 The recommendations include the following: (i) establishing strategic objectives; (ii) setting and enforcing clear lines of responsibility and accountability; (iii) ensuring that board members are qualified and conflicts of interests are monitored; (iv) ensuring there is appropriate oversight by senior management; (v) effectively using the work conducted by internal and external auditors; (vi) ensuring that incentive structures are consistent with the bank's ethical values and objectives; and (vii) conducting corporate governance in a transparent manner.

7 The uniqueness of the activities of central banks makes it difficult to apply standard efficiency measures, as discussed by, for example, Mester (2003).
} 
Although central banks and commercial corporations have similar principal-agent challenges - many central banks began operations as commercial monopolies - there are also some important differences. First, the objectives of a central bank and a commercial corporation differ. Central banks often have price stability, or a similar formulation, as an objective, or increasingly as their primary objective. Some central bank laws explicitly stipulate that profit maximization is not an objective, presumably since it may adversely affect achieving price stability. Financial autonomy, nevertheless, is important for a central bank to fulfill its functions (Ize, forthcoming; Martínez-Resano, 2004; Stella 2003; Sullivan, 2003; and Lybek 1998). In contrast, corporations have one clearly defined objective, namely to - at least in principle — maximize shareholder wealth.

Second, the governing bodies and committees of central banks have, with increased autonomy, been delegated more influence on interpreting, formulating, and implementing their objective(s). ${ }^{8}$ These differences result in additional complexities compared to corporations when designing the governing bodies and reporting requirements to stakeholders - particularly financial reporting. ${ }^{9}$ Only a handful of central banks ( 9 of the 101 surveyed laws) are joint stock companies and even fewer have private shareholders ( 5 of the surveyed laws), but with strict limits on profit allocation to private shareholders. ${ }^{10}$

Furthermore, boards in central banks, in contrast to many joint stock companies, often play a less important role in nominating and appointing the chief executive officer.

A good governing structure, however, will not alone guarantee that a board will work well (Leblanc and Gillies, 2003). Sound elements of a good governance structure included in a central bank law or bylaws are just building blocks, while the cement ensuring a solid structure are the quality and integrity of the persons performing the various functions. The nomination and appointment procedures are thus particularly important for good governance. It is also beneficial if the fiduciary responsibilities of the members of the governing bodies be

\footnotetext{
${ }^{8}$ Tuladhar (forthcoming) is reviewing the structure of governance bodies of inflation targeting central banks.

${ }^{9}$ It is generally recommended that central banks use international financial reporting standards (IFRS), provided the central bank law explicitly stipulates that unrealized profits shall not be included in profits available for distribution to the government and shareholders. This prevents a monetization of unrealized revaluation gains. Furthermore, recapitalization bonds may need to observe special criteria to avoid a qualified audit, when IFRS are used. It is outside the scope of this paper to discuss the pros and cons of special central bank accounting standards. For a discussion of financial reporting of central banks, see Sullivan (2003 and 2000), and for its importance for credibility, see Stella (2003).

${ }^{10}$ The following countries, among others, still have central banks with private shareholders: Austria, Belgium, Greece, Italy, Japan, Pakistan, South Africa, Switzerland, and the U.S. Federal Reserve Banks in the United States - with the Federal Reserve Board being a federal entity.

Private shareholders may facilitate accountability, as often intended for older central banks that were private commercial monopolies, given that the governance structure occasionally was better defined in corporate law. However, a private shareholder in the South African Reserve Bank has recently proposed to increase the profit distribution to private shareholders from 10 percent per share to 10 percent of the net profits (de Jager, 2004). Private shareholders trying to get a larger share of the profits resulting from a monopoly given to them by the government shows the down-side of such an arrangement.
} 
explicitly stated - that is their duties to the central bank, to all stakeholders, present and future, and not just to an individual or group of stakeholders.

This paper focuses on monetary authorities. Many central banks, however, are currently revisiting their framework for financial sector stability (Oosterloo and de Haan, 2003). Even if the central bank does not supervise financial institutions, it is typically responsible for overseeing the payment systems and will need, as lender of last resort, to coordinate with banking supervisors. The same guiding principles for monetary policy of ensuring consistency among objectives, authority, degree of autonomy, and accountability should also be used for financial regulators (Quintyn and Taylor, 2003; and Abrams and Taylor, 2000).

However, banking supervisors often have broader and competing objectives. A banking supervisor may be obligated to ensure a sound and effective banking system, protect depositors, and guard consumers against poor business practices. Moreover, the consequences of a regulator's authority are usually more visible than those of a monetary authority and directly affect the property rights of market participants. A regulator is able to impose penalties, including revoking licenses, which can result in explicit losses. This demands special accountability provisions, as discussed by Hüpkes, Quintyn, and Taylor (forthcoming), particularly related to the court where affected parties may be able to claim redress.

It is generally accepted that price stability should be the primary objective of a central bank. Both financial sector stability, which reduces the intermediation costs between savings and investment, and price stability, which reduces the noise in price signals, ensure a more effective and efficient allocation of scarce resources in a market-based economy. While mutually consistent in the longer term, these objectives may compete in the short run. To avoid a situation where a central bank eases the monetary policy stance to temporarily alleviate financial sector concerns instead of addressing the underlying structural weaknesses that caused these problems, price stability should, in our view, be given priority. Without prejudice to price stability, a central bank should ensure financial sector stability. Without prejudice to these two objectives, a central bank would usually support the general economic policies of the government, which facilitates coordination.

This paper focuses on the structure and design of the governing bodies and management of monetary authorities as one contributing factor to good governance. The findings are based on a survey of 101 laws on central banks and monetary authorities in force at end-2003. ${ }^{11}$ The survey reveals many different structures of governing bodies and management, which reflect a wide range of country specific factors. This study recommends that an appropriate

${ }^{11}$ A list of the countries included in this survey can be found in Appendix II. This survey includes three monetary unions. In the European Economic and Monetary Union (EMU), each member has its own central bank law in addition to the law of the union-although not all EMU members are included in this survey. The member countries of the Central African Monetary Union and West African Monetary Union do not have their own central bank law, thus only the law of the union is included. Therefore, the number of countries in this survey (113) is higher than the number of central bank laws (101). 
balance, depending on country specific conditions, be struck between the functions of the governing bodies and simplicity. The governance functions can better be identified if there is a clearer understanding of the degree of autonomy delegated to the central bank. The objectives, tasks, and functions of the central bank should be determined, which implies the extent of the authority and powers that must be delegated to the bank, whereupon the accountability provisions and the governance structures follow logically, bearing in mind country specific conditions.

The rest of this paper is organized as follows. Section II presents a framework for classifying central banks according to the autonomy delegated to them. This facilitates identifying the five typical functions of boards discussed in Section III. Section IV reviews the surveyed laws regarding the structure, size, composition, appointment, and terms of the members of the different types of governing bodies and management. Section V concludes the paper.

\section{Analytical Framework for Determining the Degree of Autonomy}

The functions of the governing bodies of a central bank depend on the degree of autonomy delegated to the bank. The first step is to clarify the extent to which the underlying premises for central bank autonomy and accountability-summarized in Box 2-are acknowledged. It is the prerogative of the state to formulate and implement monetary policy, as well as to ensure a sound financial system fostering an efficient resource allocation. If these premises are generally accepted, it is rational to delegate this authority to an autonomous institution, provided that this institution has clearly defined and prioritized objectives and sufficient powers to achieve these objectives, while being held accountable to ensure checks and balances. The acceptance of these premises depends on a wide range of country specific factors, including history, customs, and legal environment, as summarized in Box 3 . The next step entails determining the objectives, tasks, and functions of the bank from which the authority and powers necessary to achieve them follow. From these decisions the accountability provisions follow logically, whereupon the structure of the governing bodies can be designed. The main elements of these steps are summarized in Figure 1.

\section{A. Different Types of Central Bank Autonomy}

The type of autonomy delegated to the central bank will affect the functions of its governing bodies. A distinction can be made among the following kinds of autonomy: (i) goal autonomy, (ii) target autonomy, (iii) instrument autonomy and (iv) limited autonomy. ${ }^{12}$ While different classifications depending on other factors are possible, this distinction focuses on the objective(s) of the central bank and responsibility for monetary policy

12 Debelle and Fischer (1994) and other literature only distinguish between goal/target autonomy and instrument autonomy, but Lybek (1999 and 1998) also distinguishes between goal and target autonomy. 


\section{Box 2. Premises for Central Bank Autonomy and Accountability}

The primary purpose of the state is to maximize sustainable wealth, while leaving the distribution and welfare to the politicians. Welfare economics suggests that a change should be made if somebody is better off by the change and nobody is worse off (the Pareto criterion) and when the social welfare function can be improved (Bergson criterion).

Price and financial sector stability are conducive to sustainable real economic growth in a market economy. High and variable inflation creates noise, impeding the price mechanism in efficiently allocating scarce resources.

Inflation is primarily a monetary phenomenon which can only be influenced by the central bank in the medium term. Even with regulated prices, inflation will emerge and affect unregulated prices and create rationing and grey markets.

A credible monetary policy can reduce inflation at lower costs. Attempts to stimulate output above its potential - the expectation augmented Phillips curve - are futile. Short-term price stickiness can be exploited by unexpected inflation and result in a slower adjustment to new relative prices, but it postpones adjustment to permanent changes and creates an inflation bias, which impedes an efficient resource allocation. The only way to facilitate sustainable economic growth is to address underlying structural deficiencies.

Politicians have many competing objectives in the short run, and it may be tempting to manipulate monetary policy by temporarily exploiting short-term price stickiness. Even if they state that they will pursue price stability, the general public knows that the politicians have strong incentives to manipulate monetary policy (the time-inconsistency problem, according to Kydland and Prescott, 1977). The temptation to manipulate is particularly pronounced up to elections, creating election cycles (Maloney and others, 2003). The general public will therefore demand a higher real interest rate to compensate for this inflation bias, which hampers sustainable growth. A "conservative central banker" weighting price stability higher than the social objective function to neutralize the myopic behavior of the politicians is thus optimal (Rogoff, 1985).

Imperfect information demands flexibility, discretion, and specialist expertise, and the conduct of monetary policy may thus best be left to an autonomous central bank (Romer and Romer, 1997). It is the prerogative of the state to conduct monetary policy, but it can only remain credible if it follows a simple rule, which can result in substantial adjustment costs. Although a contingent rule is more flexible, it will not remain credible unless pursued by an autonomous body. The optimal reduction of the adjustment cost is to use all information rationally (Buiter, 1981), but this flexibility is only credible if conducted by an autonomous central bank. Even if the politicians' preference for price stability was credible, the electorate knows the politicians have imperfect information about the ever-changing economy (the underlying structural model) as well as the continuously changing information set. It is thus rational for them to delegate this authority to a generally better informed central banker - thus creating an indirect democratic institution (Piketty, 1999).

Checks and balances, or accountability, must be in place to prevent abuse of power by autonomous institutions. A clearly defined arrangement must be determined between the principal - whether it be between the legislature, the head of state, the cabinet, or the minister of finance representing the general public - and the agent - the central bank (Persson and Tabellini (1993) and Walsh (1995)).

Central banks should provide timely, transparent, and reliable information to the general public. Disseminating such information alleviates market failures caused by heterogeneous and imperfect information and reduces uncertainty, which contributes to a more efficient resource allocation and hence reduces the sacrifice ratio (Chortareas, Stasavage, and Sterne (2002), and Cecchetti and Krause (2002)).

Central bank autonomy, accountability, and transparency are also beneficial in countries with otherwise weak political institutions. The above premises are based on the implicit assumption of a democratic market economy with a free press that will react on the information provided, which will facilitate discipline and help prevent excesses. However, even in countries with other systems, it is important to have an appropriately designed central bank law with a view to promote efficient allocation of scarce resources. 
or the exchange rate regime. ${ }^{13}$

- Goal autonomy entrusts the central bank with responsibility for determining the monetary policy and exchange rate regime, or simply the monetary policy if the exchange rate is floating. Goal autonomy, in principle, gives the central bank authority to determine its primary objective from among several objectives included in the central bank law or, rarely, to determine the objective if there is no clearly defined objective. Thus goal autonomy is the broadest degree of autonomy and authority. A case in point is the Federal Reserve System in the United States, which includes both full employment and price stability among several potentially competing objectives. ${ }^{14}$

- $\quad$ Target autonomy also entrusts the central bank or monetary authority with responsibility for determining monetary policy and the exchange rate regime, or simply monetary policy where the exchange rate is floating. In contrast to goal autonomy, target autonomy has one clearly defined primary objective stipulated in the law. The Statute of the European System of Central Banks (ESCB) and the European Central Bank (ECB) is one example where the primary objective is price stability with the target determined by the ESCB. ${ }^{15}$

- Instrument autonomy implies that the government or the legislature decides the monetary policy target, in agreement with the central bank, or the exchange rate regime, but the central bank retains sufficient authority to implement the monetary policy target using the instruments it sees fit. One example is the Reserve Bank Act of

\footnotetext{
${ }^{13}$ The European Monetary Institute (1998), the predecessor to the European Central Bank (ECB), used the following categories to assess whether the respective central banks were sufficiently autonomous: institutional independence, personal independence, functional independence, and financial independence as discussed by Amtenbrink (1999), for example, and further elaborated by the ECB (2004). These terms all cover important aspects of autonomy, but they are not different types of autonomy, but rather different elements of autonomy.

${ }^{14}$ According to Sec. 2A of the Federal Reserve Act: "The Board of Governors of the Federal Reserve System and the Federal Open Market Committee (FOMC) shall maintain long-run growth of the monetary and credit aggregates commensurate with the economy's long-run potential to increase production, so as to promote effectively the goals of maximum employment, stable prices, and moderate long-term interest rates."

15 Article 2 of the Statute of the ESCB and of the ECB: "In accordance with Article 105(1) of this Treaty, the primary objective of the ESCB shall be to maintain price stability. Without prejudice to the objective of price stability, it shall support the general economic policies in the Community with a view to contributing to the achievement of the objectives of the Community as laid down in Article 2 of this Treaty. The ESCB shall act in accordance with the principle of an open market economy with free competition, favoring an efficient allocation of resources, and in compliance with the principles set out in Article 3a of this Treaty."
} 


\section{Box 3. Selected Country-Specific Factors Affecting the Central Bank Governance Structure}

Economic development influences the objectives, tasks and functions of a central bank and thus the structure of its governing bodies. The demographic structure - particularly the age structure of the populationaffects the preference for price and financial sector stability. In low-income countries without income and valueadded tax systems in place, an inflation tax may be a more realistic second-best solution, in spite of higher real interest rates and lower revenue due to tax collection lags (Tanzi-effect). Furthermore, if the more influential groups are less reliant concerning financial sector instruments adversely affected by inflation, this may reduce their preference for price stability (Posen, 1995). Culture also seems to affect the preference for price stability and hence central bank autonomy (de Jong, 2002). Development may, in low-income countries, be one of the objectives of the central bank, resulting in quasi-fiscal activities (as discussed by Unakul and Panitchpakdi, 1978). In addition, central banks in developing countries often rely more on direct monetary instruments that have a direct impact on the resource allocation, which creates a stronger political interest in the implementation of monetary policy.

Historical traditions, culture, and customs influence the governance structure. Central bank laws are rarely completely redesigned. Instead, they are typically amended with a view to limit the changes, which, together with path dependence, creates inertia.

The political system affects the premises for central bank autonomy and accountability (Box 2). A leader representing a specific group(s) may be more interested in the wealth of these groups than creating sustainable wealth for the general public. If the leader or party does not have to be reelected, there is less risk for election cycles. In these cases, accountability may primarily be designed to avoid defrauding resources at the expense of these groups, and the central bank is more likely to become a government agency. Political realities must be acknowledged, but one way to mitigate the perception of a "weak" state environment is to reduce the inflation bias and grant more autonomy to the central bank. Legal protection against arbitrary dismissal becomes particularly important. The governance structure of a central bank - whether it is accountable to the legislature, head of state, cabinet, or minister of finance-will reflect the political system. In one small country, for instance, a practice has developed where the elected head of state functions as both minister of finance and governor of the central bank. Legal traditions affect several aspects of the governing bodies of a central bank. Most central banks are corporate bodies, fully state-owned, and governed by a central bank law, but a few central banks are joint stock companies and have private shareholders. The governance structure is usually influenced by the traditions from corporate law. In Anglo Saxon countries, for instance, most corporations have one board, while in some continental European countries, it is the tradition to have two boards: a governing board and a supervisory board (see, Branson (2001) and Hopt and others (1998) for an overview).

Some countries entrench the more important provisions regarding the central bank in the constitution. Older constitutions are often remarkable silent about the central bank. Only a few constitutions, like the one in South Africa, explicitly specify the objective of the central bank. Several Latin American countries, after the problems in the early 1980s, have amended their constitution to include fairly detailed provisions on the central bank, including prohibiting direct central bank credit to the government (Gutiérrez, 2003). Constitutions in transition countries often have provisions regarding the authority to nominate and appoint the governor and other board members.

The details of a central bank law and the frequency of amending it differ widely among countries. Depending on the legal environment, which include traditions, customs, and jurisprudence affect the level of detail in the central bank law. Some central bank laws are quite detailed, such as the Federal Reserve Act in the United States, while others include less detail, but may rely more on by-laws. In Indonesia, for instance, the elucidation of the central bank law is just as important as the law itself. In some countries, the central bank law is amended several times each year, perhaps by decree. The Kazakhstani Central Bank Law of March 30, 1995 has, until end2003, been amended 16 times. In other countries, the central bank law is rarely amended. The Danish Central Bank Act dates back to 1936 and has only been amended four times (1938, 1939, 1967, and 1969 — only minor amendments). A balance between the detail of the law, including the right of the government to override the central bank in extreme cases, the need for amending the law to reflect changing conditions, and the political process for amending the law (Moser, 1999) influence the extent to which a central bank law provides assurances to the general public and helps reduce the inflation bias. 
Figure 1. Factors in Designing a Consistent Governance Structure

\section{Country-specific factors}

a. Acceptance of premises on autonomy and accountability

b. Economic development

c. State structure

d. Legislative traditions

\section{Objectives, Autonomy and Authority}

a. Macro and micro objectives

b. Authority and powers

c. Autonomy to utilize authority

d. Conflict resolution mechanism

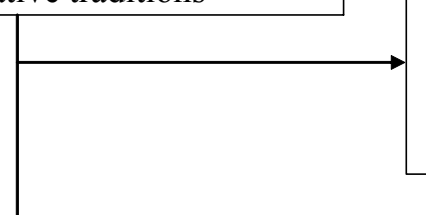

\section{Accountability for}

a. Objectives and tasks

b. Authority and powers

c. Financial condition

d. Efficient use of resources

New Zealand. ${ }^{16}$ There may also be a contract or an agreement between the government and the central bank that is not explicitly stipulated in the central bank law, as for example in Canada and Norway. Usually currency board arrangements will also be considered having some degree of instrument autonomy, unless the central bank has the authority to determine that a currency board arrangement shall be the monetary anchor.

- $\quad$ Limited or no autonomy means that the central bank is basically a government agency. The government determines the policies (objectives and targets) as well as influences the implementation. The latter is the case mainly in centrally planned economies and in some developing countries.

\footnotetext{
${ }^{16}$ Article 8 of the Reserve Bank Act of New Zealand stipulates: “...The primary function of the Bank is to formulate and implement monetary policy directed to the economic objective of achieving and maintaining stability in the general level of prices." Article 9(1) stipulates: "The Minister shall, before appointing, or reappointing, any person as Governor, fix, in agreement with that person, policy targets for the carrying out by the Bank of its primary function during that person's term of office, or next term of office, as Governor."
} 
Goal and target autonomy are perceived as strong degrees of autonomy, but they also raise the question why central bankers, who are not elected by the general public, should have the authority to decide the short-term tradeoff between the rate of inflation and employment. By delegating policy decisions to a non-elected — what has been coined by Rogoff as"conservative central banker," some argue that a so-called democratic deficit is created. Particularly in countries having experienced the adverse effects of inflation, a so-called democratic deficit may be considered preferable to leaving it to politicians to determine the level and variability of inflation, since they face many other competing objectives in the short run. While goal and target autonomy reduce the inflation bias, lack of sufficient authority to actually enforce these objectives could result in the central bank choosing a less ambitious target and lacking credibility.

Although instrument autonomy may be perceived as a lesser degree of autonomy, in many cases it has proven sufficient to provide the general public with assurances that the implementation of monetary policy will not be manipulated by the government, which may be sufficient to address the time-inconsistency problem (Fischer, 1995a and b). Even without an inflation bias, instrument autonomy can be optimal for a politician, assuming the central bank has a longer time horizon allowing it to better exploit new information and learn, ideally with some possibilities for removing incompetent office holders (Eggertsson and Le Borgne, 2003). In this type of autonomy the political decision makers retain the authority for determining the target - a commitment must remain over the medium term to avoid the inflation bias - thus avoiding the perceived democratic deficit, which is also likely to advance coordination and consistency with other policies.

If the primary motivation for autonomy is better informed central bankers (Romer and Romer, 1997) having longer time horizons (Blinder, 1998), rather than time-inconsistency, instrument autonomy is not sufficient to achieve an optimal solution. Provided the paradigm that price stability is the best contribution monetary policy can make to sustainable growth, target autonomy should be chosen, since the politicians are less likely to be fully informed about potential output. If this paradigm is not accepted and more emphasis is put on the sacrifice ratio, it is sensible to adopt goal autonomy. This assumes that specialized central bankers are generally better informed about the elusive and ever-changing underlying structural model, and thus less likely to push output above its potential.

Table 1 shows the grouping of surveyed central bank laws using the above discussed categories of central bank autonomy. Over half of the surveyed countries have delegated goal or target autonomy to the central bank. The largest group of the surveyed countries (42 laws) practices target autonomy. More than half of lower- and middle-income countries have instrument autonomy, mainly due to an exchange rate peg. It seems that relatively more lowincome and middle-income countries have central banks with diminished autonomy-as explained below-within a given type of autonomy.

This classification is sensitive to the authority over the exchange rate policy and the extent to which a central bank is in effect autonomous. In this survey, however, with a view toward achieving a more comprehensive view of the types of governing structures, central banks 
Table 1. Type of Autonomy in Selected Central Bank Laws, end-2003

\begin{tabular}{|c|c|c|c|c|c|c|}
\hline & $\begin{array}{r}\text { Goal } \\
\text { Autonomy }\end{array}$ & $\begin{array}{r}\text { Target } \\
\text { Autonomy }\end{array}$ & $\begin{array}{l}\text { Instrument } \\
\text { Autonomy }\end{array}$ & $\begin{array}{l}\text { Limited } \\
\text { Autonomy }{ }^{1 /}\end{array}$ & \multirow{2}{*}{\multicolumn{2}{|c|}{$\begin{array}{c}\text { Total } \\
\left.{\text { (diminished autonomy })^{2 /}}_{(\text {number of laws }}{ }^{3 /}\right)\end{array}$}} \\
\hline & \multicolumn{4}{|c|}{ (percent of laws in each group) } & & \\
\hline High income & 11 & $46^{4 /}$ & 36 & $7^{5 /}$ & 100 & $28 \quad(5)$ \\
\hline Upper middle income & 16 & 42 & 42 & -- & 100 & 12 \\
\hline Lower middle income & 16 & 29 & 52 & 3 & 100 & 31 (12) \\
\hline Low income & 20 & 50 & 13 & 17 & 100 & $30 \quad(20)$ \\
\hline Total & 16 & 42 & 35 & 7 & 100 & $101(41)$ \\
\hline
\end{tabular}

Source: Selected central bank laws. Information on the classification of individual countries can be requested from the authors of this paper. Income classification as defined in World Bank Atlas of August 21, 2003.

${ }^{1 /}$ Central bank laws where the central bank basically is a government agency.

${ }^{2 /}$ Diminished autonomy means that there are important deficiencies vis-à-vis good practices as defined in Appendix II.

3/ Number of surveyed laws.

4/ Includes the members of the European Monetary System - defined as the European Central Bank plus the national central banks that have adopted the euro-covered in this survey.

5/ Mainly Middle Eastern oil-exporting countries included in this survey.

with limited autonomy having broader authority than just being a government agency are classified as having diminished autonomy, but are still classified as having goal, target, or instrument autonomy.

\section{Exchange rate policy}

Historically, the government (usually the cabinet), not the central bank, has determined the exchange rate regime, and this is still the case in about two-thirds of the surveyed countries (Table 2). The implementation of the exchange rate policy, including determining the exchange rate within the regime, is normally left to the central bank. Newer central bank laws increasingly delegate the authority over the exchange rate regime to the central bank. With capital account liberalization and increased capital mobility, monetary and exchange rate policy are intrinsically linked. It is therefore often argued that the central bank should also be in charge of the exchange rate policy, since the exchange rate simply reflects the relative balance between money supply and demand (Cottarelli, 1994). This approach, however, ignores short-term money illusion, price stickiness, and the fact that the real exchange rate is affected by a range of policies that remain under the authority of the government. In short, even with increased capital mobility and stronger central bank autonomy, coordination and conflict resolution procedures between the government and the central bank are still important in a central bank law.

As noted previously, if the government pegs the exchange rate or follows a specified pattern, while leaving the implementation to the central bank, this is classified as instrument autonomy, since the anchor is determined by the government. If the government legally has 
Table 2. Authority over Exchange Rate Policy, end-2003

\begin{tabular}{|c|c|c|c|c|c|c|}
\hline & \multicolumn{2}{|c|}{ Central Bank determines: } & \multicolumn{2}{|c|}{ Government determines: } & \multicolumn{2}{|c|}{ Total } \\
\hline & $\begin{array}{r}\text { exchange } \\
\text { rate } \\
\text { regime }\end{array}$ & $\begin{array}{r}\text { in consultation } \\
\text { with } \\
\text { government }^{1 /}\end{array}$ & $\begin{array}{r}\text { exchange } \\
\text { rate } \\
\text { regime }\end{array}$ & $\begin{array}{r}\text { in consultation } \\
\text { with central } \\
\text { bank }^{1 /}\end{array}$ & & \\
\hline & & (percent of & ws in each gr & up) & & $\left.e^{2 /}\right)$ \\
\hline High income & -- & 4 & 4 & $92^{3 /}$ & 100 & 28 \\
\hline Upper middle income & 18 & 18 & 9 & 55 & 100 & 11 \\
\hline Lower middle income & 16 & 22 & 10 & 52 & 100 & 31 \\
\hline Low income & 6 & 43 & 6 & 45 & 100 & 31 \\
\hline Total & 9 & 24 & 6 & 61 & 100 & 101 \\
\hline
\end{tabular}

Source: Selected central bank laws. Information on the classification of individual countries can be requested from the authors of this paper. Income classification as defined in World Bank Atlas of August 21, 2003.

1/ Include countries where the central bank law clearly stipulates that consultation is required. In practice, consultation will always take place.

2/ Number of surveyed laws.

3/ Members of the European Monetary System - defined as the European Central Bank plus the national central banks that have adopted the euro-covered in this survey.

the authority over the regime, but has decided to float, while the formulation of monetary policy resides with the central bank, in this survey it has been classified as target or goal autonomy, provided other conditions are observed. This helps explain why 58 percent of the surveyed laws have goal or target autonomy, while the government formally has the authority over the exchange rate regime in about two-thirds of the surveyed laws. Particularly in small open economies, the exchange rate policy plays an important role as the nominal anchor. Countries having clearly delegated the authority over the exchange rate regime to the central bank, among others Latvia, are typically small open economies, having reached, or are envisaging full capital account liberalization.

Whatever type of autonomy delegated to the central bank, conflict resolution procedures with the government are important to avoid an autonomous central bank feeling obligated to accommodate government policies that adversely affect its monetary policy. Even if the central bank is in charge of determining the exchange rate regime and is prohibited from extending direct credit to the government, there may still be a need for a conflict resolution mechanism, since government policies may adversely affect the real exchange rate and capital flows which can make it difficult for the central bank to maintain price stability. A case in point on the importance of coordination is when the government decides to finance its budget deficit abroad because it is perceived to be less expensive (owing to a nascent domestic market for government securities), while the central bank already struggles to sterilize private capital inflows.

\section{Diminished and limited autonomy}

In addition to clearly defined and prioritized objectives, other conditions listed in Appendix I must also be in place to actually reduce the inflation bias. For example, in the case of goal 
and target autonomy, if the directors are not adequately protected against arbitrary dismissal, they may be less inclined to choose a sufficiently ambitious objective and target. In the case of instrument autonomy, an agreement between the central bank and the government, with all its key elements published, must cover a long period or the target ideally will be defined by focusing on core inflation, thus excluding seasonal and other short-run factors, to fully diminish the inflation bias. ${ }^{17}$ If these broader conditions are not entrenched in the central bank law, the central bank has diminished autonomy. In the event most of these requirements are not observed, the central bank has limited autonomy, but governance challenges remain, although they are similar to other government agencies. ${ }^{18}$

While the categorization into goal, target, instrument and limited autonomy is fairly straightforward, the classification into diminished autonomy is more subjective. The classification used in this survey relies primarily on an interpretation of the central bank law, but practices that may have evolved over time and differ somewhat from the intentions of the law are also considered. Additional subjectivity in classifying autonomy comes from the importance ascribed to the different factors in Appendix I that contribute to autonomy and accountability. ${ }^{19}$

\section{B. Accountability}

The central bank's accountability provisions should ensure that it exercises its policy and functions effectively and efficiently and that it manages its resources in a cost-effective way. A central bank should be accountable to its stakeholders for its delegated functions, without prejudice to its financial condition. The latter, however, is important for protecting the central bank from encroachment on the bank's functional autonomy through stakeholders attacking the bank for misusing public resources.

The accountability provisions in most of the surveyed laws are relatively clearly defined regarding monetary policy. Traditionally, central banks have been accountable to the minister of finance, the head of state, or in a few cases the cabinet. However, newer central bank laws increasingly make the central bank accountable to the legislature for monetary policy - for

${ }^{17}$ Some central bank laws allow the government to override the central bank in case of emergencies (such as Chile in the case of war). If the government's right to instruct the central bank is frequently used, or the central bank begins to give more consideration to the policies of the government than achieving its own objectives, such a provision will impinge on the bank's credibility and recreate inflation bias. However, if such instructions are given in a transparent way and used only in extreme emergencies, credibility will be quickly reinstated after a crisis, and the provision will not impinge on the routine autonomy of the central bank.

18 The OECD (1998), for instance, advises on how to best govern public entities.

${ }^{19}$ For instance, usually lack of a prudent limit on credit to the government severely impedes autonomy in countries with poor inflation performance. However, it may be less important for a country such as New Zealand where, although no explicit limit on direct central bank credit to the government exists, a limit is implied by the inflation target agreed upon with the government. Norway also has adopted inflation targeting and has no explicit limit on credit to the government, but is in this survey classified as having diminished instrument autonomy, given that the law has other shortcomings compared to what generally is considered best practice. 
instance, more than a third of the surveyed laws (Table 3). Over half of the countries accountable to the legislature are those with target autonomy. Conversely, about half of the countries with target autonomy are accountable to the legislature. It is noteworthy that in the cases of limited autonomy more central banks are accountable to the minister of finance. In a few countries, the central bank is accountable for its monetary policy to both the legislature and the executive arm of the government, such as Paraguay and the Philippines.

Table 3. Type of Autonomy and Accountability for Monetary Policy, end-2003

\begin{tabular}{|c|c|c|c|c|c|c|c|c|}
\hline & $\begin{array}{r}\text { Head of } \\
\text { State/ } \\
\text { President }\end{array}$ & $\begin{array}{l}\text { Legis- } \\
\text { lature }\end{array}$ & $\begin{array}{l}\text { Head of } \\
\text { Cabinet }\end{array}$ & Cabinet & $\begin{array}{l}\text { Min. of } \\
\text { Finance }\end{array}$ & Other & \multirow{2}{*}{\multicolumn{2}{|c|}{$\begin{array}{l}\text { Total } \\
\text { (number }^{1 /}\end{array}$}} \\
\hline & \multicolumn{5}{|c|}{ (percent of laws in each group) } & & & \\
\hline Goal autonomy & 19 & 19 & 6 & 13 & 37 & 6 & 100 & 16 \\
\hline Target autonomy & 10 & 50 & -- & 7 & 14 & 19 & 100 & 42 \\
\hline Instrument autonomy & 9 & 34 & 8 & 6 & 37 & 6 & 100 & 35 \\
\hline Limited autonomy & -- & -- & -- & 25 & 75 & -- & 100 & 8 \\
\hline Total & 10 & 35 & 4 & 9 & 33 & 9 & 100 & 101 \\
\hline
\end{tabular}

Source: Selected central bank laws. Information on the classification of individual countries can be requested from the authors of this paper.

${ }^{1 /}$ Number of surveyed laws.

In many cases the central bank's accountability for its financial conditions is to the same body as for its monetary policy, but in several cases, the minister of finance, the president, or the cabinet plays a stronger role in monitoring the financial conditions of the central bank. For instance, in some French-influenced systems, the central bank has a special censor continuously reviewing the financial situation of the bank. The minister of finance, in most cases representing the owner, will typically have stronger incentives to closely monitor the financial conditions. In some countries, the head of state plays a role in ensuring that the bank manages its resources in a cost-effective way. It is important to strike a balance between ensuring both the financial autonomy of the central bank and its accountability.

There are different ways to ensure accountability, but timely and transparent reporting is crucial. Central banks generally publish policy statements, and in some newer central bank laws such statements must be published twice a year. These statements should report on the outcome of the previous period and state the policy for the forthcoming period. This is particularly important for central banks with goal autonomy, where it may otherwise be unclear to the general public what goal is given priority.

Central bank laws typically require that an annual report on central bank operations and externally audited financial statements be published. Although explicitly stated in only a few newer central bank laws, it is a good practice that the central bank reports on factors outside as well as inside its control affecting monetary policy. Annual financial statements are 
usually audited by an independent external auditor, the auditor general, or both. Although most central bank laws still leave the organization to the management of the bank, some countries have found it useful to explicitly require an internal auditor or comptroller be appointed. Furthermore, frequent — at a minimum monthly — publication of summary balance sheet information is good practice and stipulated in several central bank laws, which allows the general public to continuously monitor the bank. Finally, in addition to the necessary coordination with the executive arm of government, many central bank laws now explicitly stipulate that the central bank be ready to answer questions raised by the legislature (Lepper and Sterne, 2002).

\section{Changing Functions of Governing Bodies}

An appropriate governance structure can help entrench central bank autonomy and facilitate accountability by depoliticizing the process. Even for commercial corporations, which-at least in principle - have a clearly defined primary objective, namely maximizing the owner(s)' wealth, the design of the juncture — or "pinnacle" — between management and board is difficult. Corporate law differs among countries, as discussed by, for example, Branson (2001), and Hopt and others (1998). This reflects the fact that that there are many

equally acceptable ways to formalize this nexus illustrated by the ellipse in Figure 2. In contrast to shareholders of publicly listed companies, stakeholders of central banks do not always have the same recourse, which creates additional challenges for central banks.

The functions of the governing bodies of central banks have changed over time with increased autonomy (Box 4). New tasks and responsibilities of central banks imply that the positions also require new qualifications. It is, nevertheless, our experience from reviewing amendments to many central bank laws that this is not always fully appreciated. When central banks are delegated more autonomy and authority, the functions of these bodies also change and become even more different from those of a commercial corporation. Accordingly, it is useful to look further into the different functions of governing bodies in light of the degree of autonomy delegated to the central bank.

\section{DiRECTORS, OFFICERS, AND THEIR FUNCTIONS}

\section{A. Number of Boards}

Central banks have one or more boards. In this survey, 63 percent of the surveyed laws provide for one board, 23 percent have two boards, and the remaining laws provide for three or more boards (Table 4). In this tabulation, the term "board" may also include committees, if they perform one of the functions discussed in the following section. It was found in this survey that the type of autonomy delegated to the central bank does not necessarily determine the number of boards. In fact, in 78 percent of the surveyed laws, management responsibilities are solely delegated to the governor. When delegated to a management board, more often the central bank has target autonomy. 
Figure 2. The Management-Board Pinnacle

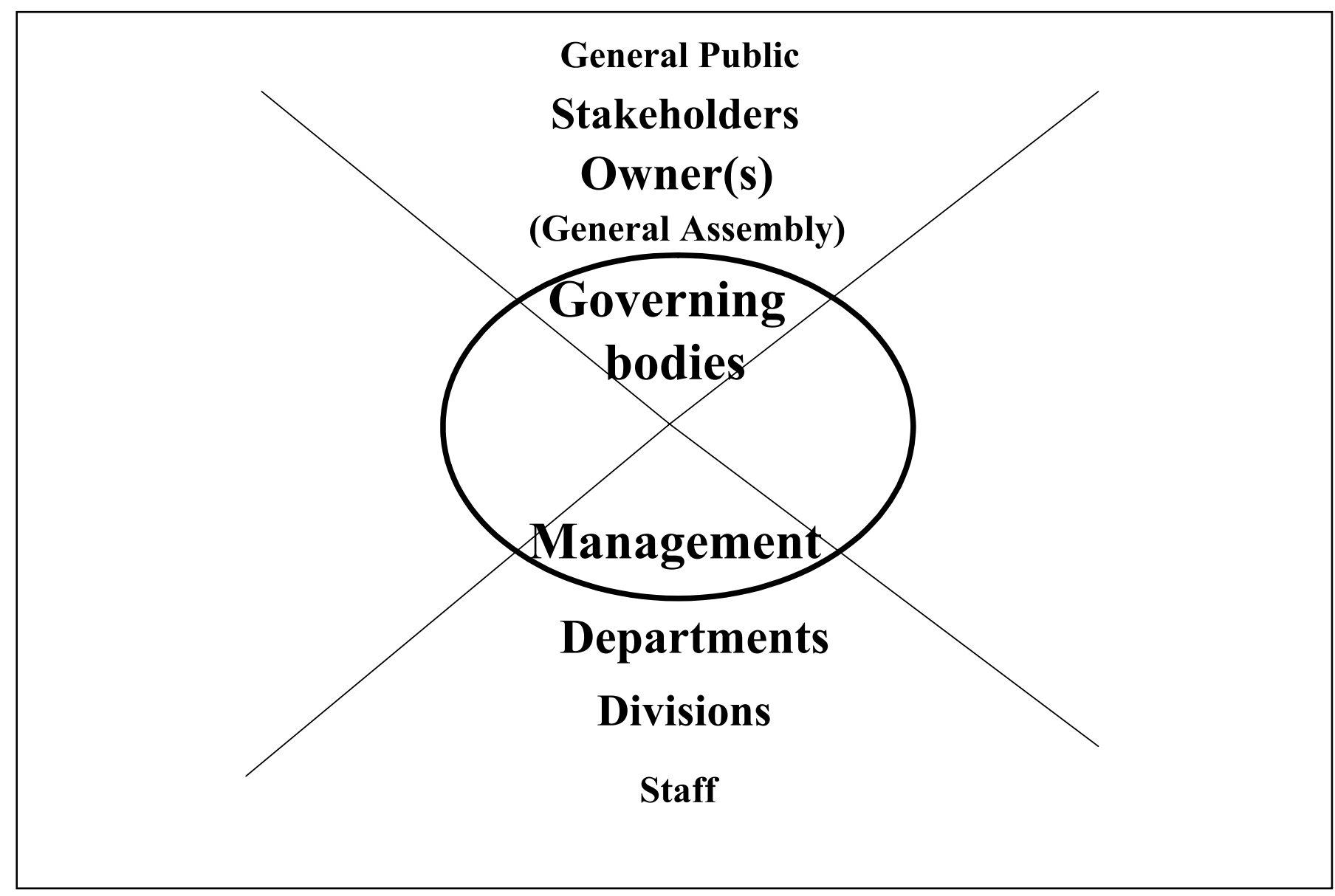

\section{B. Functions of Governing Boards and Management}

Since the functions of the various boards vary depending on the autonomy delegated to the central bank, and due to the wide range of names used for the various bodies of central banks, this paper reviews the characteristics of governing bodies of central banks in light of their functions. Furthermore, management representatives are usually members of the various boards making policy decisions at the highest level. Accordingly, this survey will classify the governance structure by distinguishing between the following boards and management to which distinct functions, including day-to-day management, are assigned.

\section{Policy boards}

A policy board determines the monetary policy and exchange rate policy, if applicable, to be followed by the central bank. In the case of goal autonomy, a policy board determines which objective to give priority. In the case of target autonomy, it specifies the target within a 


\section{Box 4. The Changing Governing Bodies of the Bank of England}

The Bank of England is an illustrative example of how the role, the functions, and governance structure
of a central bank may change over time. ${ }^{1 /}$ The Bank of England was founded in 1694 to raise funds for the
government. It was established as a commercial enterprise allowed to issue bank notes redeemable in silver
coin. It had a governor, deputy governor, and 24 directors to be elected by stockholders holding 500 or more
of stock. During the economic crisis in the 1930 s, the gold standard-a simple fixed rule-was abandoned. The
government increasingly determined monetary policy, and the Bank was nationalized with a new central bank
law being adopted in 1946 . The administration of the Bank was left largely unchanged, but the number of
members of the court-the board of the Bank-was reduced from 24 to 16 . Commercial bankers were members
of the court, which potentially created a conflict of interest. The Parker Tribunal addressed such allegations in
1958, when the Bank Rate was changed. ${ }^{2 /}$ The Banking Act of 1987 gave the Bank the role as banking
supervisor with the objective to protect the interest of depositors. In 1993, the Bank took a major step to
enhancing its transparency by issuing a quarterly Inflation Report.
In 1997, the government gave the Bank responsibility for setting interest rates to achieve the
government's inflation target. In 1998, the new central bank law became effective, the Bank became more
autonomous, and a Monetary Policy Committee (MPC) was established, while the Court remained mainly as a
supervisory board. The MPC comprises five executive members and four nonexecutive members, all chosen for
their expertise in monetary policy instead of representing specific interests. The Court comprises the Governor,
two Deputy Governors, and 16 nonexecutive Directors. A sub-committee of the Court is responsible for
reviewing the Bank's performance, although the Court as a whole is responsible. In June 1998, the
responsibility for banking supervision was moved from the Bank of England to the Financial Services
Authority.
1/ For a brief overview of the history of central banks, see, for instance, Capie et al. (1994) and de Koch (1954).
2/ For details, see Aufricht (1965), chapter 4, footnote 70.

defined primary objective. More than half of the surveyed central bank laws have a policy board, although some of these policy boards also have other functions. ${ }^{20}$ To ensure a balanced and informed view, appropriately qualified external members should be considered. Such members may alleviate concerns that the central bank is "too conservative," and to a lesser extent address the perceived democratic deficit. If the majority comprises management representatives - say the pool of qualified external members is limited - these members may be more inclined to support the governor than be true to their fiduciary responsibilities, since their career often will depend on the governor, who also usually is the chairman of a policy board.

Consideration should thus be given to including nonexecutive members on policy boards, provided such members do not have conflicts of interest and do not endanger the autonomy of the central bank. A country with instrument autonomy would not have a policy board, as the policy is set by the government. However, in a few low-income countries, even with goal

${ }^{20}$ Historically, when central banks only had limited or diminished autonomy, the policy determination function in some countries was assigned to a monetary policy committee with a strong representation of government officials. Such a committee can be either of the following: (i) a part of the central bank, as in the former central bank law of Korea or the current laws of Brazil (currently being revised) and Pakistan (the Policy Coordination Board); or (ii) it can be a body outside the central bank. In the latter case, provided this committee does not interfere in the implementation of the policies, the central bank may still have instrument autonomy. 
Table 4. Type of Autonomy and Structure of Governing Bodies, end-2003

\begin{tabular}{|c|c|c|c|c|c|c|c|}
\hline & \multicolumn{3}{|c|}{ Directors } & \multirow[t]{2}{*}{ Total } & \multicolumn{2}{|c|}{ Management } & \multirow[t]{2}{*}{ Total } \\
\hline & $\begin{array}{r}\text { One } \\
\text { Board }\end{array}$ & $\begin{array}{r}\text { Two } \\
\text { Boards }\end{array}$ & $\begin{array}{r}\text { Three or } \\
\text { more } \\
\text { Boards }\end{array}$ & & Governor & $\begin{array}{l}\text { Govern- } \\
\text { ing Board }\end{array}$ & \\
\hline & \multicolumn{6}{|c|}{ (percent of laws in each group) } & (number ${ }^{1 /}$ ) \\
\hline Goal autonomy & 69 & 19 & 12 & 100 & 94 & 6 & 16 \\
\hline Target autonomy & 55 & 24 & 21 & 100 & 67 & 33 & 42 \\
\hline Instrument autonomy & 69 & 25 & 6 & 100 & 83 & 17 & 35 \\
\hline Limited autonomy & 88 & -- & 12 & 100 & 88 & 12 & 8 \\
\hline Total & 63 & 23 & 14 & 100 & 78 & 22 & 101 \\
\hline
\end{tabular}

Source: Selected central bank laws. Information on the classification of individual countries can be requested from the authors of this paper.

${ }^{1 /}$ Number of surveyed laws.

and target autonomy, the governor plays a particularly strong role in both the formulation and implementation of monetary policy. ${ }^{21}$

\section{Implementation boards}

An implementation board makes decisions on how to implement the target(s), for instance, to increase or decrease key interest rates to support an inflation target or an exchange rate. In the case of goal and target autonomy, the implementation board is often the same as the policy board. It might also be the management board. A majority, or even the entire board, could comprise management representatives, since these decisions are more of a technical nature, and the pool of qualified external members may be limited. As previously mentioned, if the careers of internal members depend on the governor, who often is the chairman of the implementation board, the members may be more inclined to support the governor than be true to their fiduciary responsibilities. In the case of instrument autonomy, these decisions are the highest priority of the central bank. Generally, they are delegated to a board, but occasionally they may be taken by one person-as in the case of New Zealand. ${ }^{22}$ A small board, or implementation by the governor, avoids dilution of responsibilities and facilitates accountability, but it also delegates substantial responsibility to very few people. ${ }^{23}$

\footnotetext{
${ }^{21}$ In Papua New Guinea, for instance, the governor is in charge of monetary policy and oversight, while the board makes decisions on other aspects, such as supervision and payment systems.

22 Svensson (2001) found, in a review of Monetary Policy in New Zealand that the governor being the single decision-maker worked well, but also that it was "too risky" and recommended a formal monetary policy committee.

${ }^{23}$ It is often argued that on average, group decisions are superior to individual decisions (see for instance, chapter 2 in Blinder 2004, and Blinder and Morgan, 2000). King (2002), for instance, when discussing the experience of the Monetary Policy Committee of the Bank of England, argues that a committee makes better informed decisions, since the members quickly learn to put more weight on better performing members, but still allow all members to share and learn from each other.
} 


\section{Advisory boards}

Advisory boards advise the policy boards, implementation boards, or even management. They may have been introduced to address concerns that Rogoff's (1985) "conservative central banker" may be perceived as being too conservative. Such boards can contribute by providing a more balanced view. They may also be used to address regional concerns (among others, the Central African Monetary Union), involve representatives from different economic sectors (such as in Portugal), or include former governors (e.g., Cape Verde). Only 10 of the surveyed laws have mandated advisory boards. Another way to ensure relevant expertise is being brought to bear during deliberations is to invite experts to participate in board meetings without the right to vote. Another approach, which is quite common, is to allow the establishment of committees, or subgroups of the board, which can study a problem in detail based on inputs from experts.

\section{Supervisory boards}

Supervisory boards are responsible for overseeing and addressing any problems regarding the following conditions: (i) achieving objectives, tasks, and functions, (ii) the financial condition of the central bank, (iii) effective internal controls, and, in some cases, also (iv) efficient use of its resources. Since a central bank should not maximize profits at the expense of price stability, the prudent use of resources can be stressed. Particularly important is its role in reviewing cases of gross negligence or gross misconduct by the governor and other board members, and approving the annual report, budget, and financial statements before such information is published.

The composition of the supervisory board can help depoliticize the supervisory process, provided its tasks and powers are clearly defined. If only one board exists and it is mainly a governing board without clearly defined oversight responsibilities, there may be more valid reasons for the government or legislature - representing the general public - to intervene or even require that their representatives be on the board to ensure oversight. However, a poorly designed supervisory board with strong political figures can also be used to unduly influence the central bank. In some countries, where these concerns are important, the supervisory function of the central bank's financial condition has been limited to its administrative costs, to ensure that, for example, sterilization costs are excluded from the appropriation process. In some of the Scandinavian countries, politicians are members of the supervisory board, but generally acceptance of the importance of central bank autonomy and democratic traditions help ensure that these boards focus on their supervisory responsibilities. Such members can actually function as spokesmen for the central bank in the legislature. A properly designed supervisory board - bearing in mind country specific conditions - can both entrench the autonomy delegated to the central bank and strengthen its credibility.

\section{Audit committees}

Audit committees assist in performing the supervisory function and are mainly an AngloSaxon tradition for corporations having only one board. Usually these boards are rather 
large and there may be a need for special expertise to address issues of internal control and financial disclosure. ${ }^{24}$ Only a few of the surveyed central bank laws-for example, those of Cambodia and Nepal - formally require the establishment of an audit committee, while some central banks, such as the Central Bank of Bosnia and Herzegovina, have adopted this practice, although it is not stipulated in the law. Some central bank laws, such as in Mozambique, use the term "Audit Committee," but its role is really more that of a supervisory board with responsibilities for the financial condition of the central bank. In Portugal, the board of auditors covers functions usually assigned to both an audit committee and a pure supervisory board. As previously mentioned, in some countries - such as Morocco and Tunisia - it is a legal tradition to have a "comptroller," or censor, who is appointed by the minister of finance, and performs some of the functions of an audit committee. Even in case of a small board it may be useful to contract specialist expertise, which could be done in the form of an audit committee, but safeguards must be in place to ensure the autonomy of the bank.

\section{Management}

Management has the primary responsibility for the day-to-day operations of the central bank. In 78 percent of the surveyed laws, this responsibility is delegated to one person, who usually is named governor, chairman, president, or general manager. The governor is typically assisted by one or more deputy or vice governors, a general manager, or a board comprising directors of various departments of the bank. Where a management board is established in the law, it usually comprises the governor, deputy governor(s), and in some cases directors of the most important departments of the bank.

\section{Boards Performing Several Functions}

Often a single board performs more than one of the above discussed functions. It then becomes increasingly difficult to design the appropriate composition of the board. This is the case in numerous countries, since 63 percent of the surveyed central bank laws have one board. Only a few central banks, such as the National Bank of Hungary, have rather clearly specified different functions to different bodies as discussed in the above section.

In the case of a country with goal or target autonomy, if there is one board, then it performs the policy, implementation, and supervisory functions. In the case of a country with instrument autonomy, if there is one board, it often performs both the implementation and supervisory functions. If a management board exists, it may, in addition to its management function, also play a specified role in determining policies and how to implement them. This is useful for coordination and ensures that realistic targets are set. Multiple functions in one board, however, raise some interesting questions. For example, if a supervisory board also functions as a policy board or an implementation board, it might be tempting for the policy

${ }^{24}$ PriceWaterhouseCoopers (1999) has issued a pamphlet on Audit Committees: Good Practice for Meeting Market Expectations. 
board to determine a less ambitious target, making it easier to over-perform, as it basically oversees itself.

Furthermore, some countries have a board with special functions. In Australia, for instance, the central bank has a special Payment System Board. Since board members are liable for their decisions, and payment system policies require special experience, it was decided to establish a separate payment system board. The Reserve Bank Act clearly defines how to resolve conflicts between the Reserve Bank Board and the Payment System Board. Particularly if it is deemed useful to have industry representation, consideration could be given to establish specialized boards. However, the same benefits may be achieved by establishing special committees. Industry representatives should not make decisions regarding individual institutions but ensure an informed and balanced view when policies are discussed to avoid any benefit from insider information. If a central bank has several boards responsible for different functions, it can easily create problems. It is crucial that the tasks and authority of the various specialized boards be clearly and consistently defined and that the law describes how conflicts shall be resolved in case of overlapping responsibilities.

\section{IMPORTANT ELEMENTS OF BOARDS AND MANAGEMENT}

\section{A. Size of Boards}

The size of the respective boards should strike a balance between having a sufficient number of members to ensure an informed, balanced, and professional view, while at the same time limiting the number so that the board remains effective and avoids a dilution of individual responsibilities. Reportedly, board members sometimes feel an obligation to speak, which can be time consuming if they do not contribute with new information or perspectives. Most policy boards have seven to nine members (Table 5). Supervisory boards and advisory boards, on the other hand, often have a broader representation. Where a management board exists, it tends to be smaller, thus allowing for quick decisions and avoidance of the dilution of responsibilities. In this survey, only the body with the primary responsibility for a function is included in the following tables. Accordingly, the evidence is somewhat blurred by the fact that many of these boards perform more than one of the discussed functions.

\section{B. Chairmanship of Boards}

The role as chairman is particularly important, since the chairman can call meetings, influence the agenda, and in most cases has the casting vote in case of a tie. The governor is always the chairman of a management board, usually the chairman of an implementation board, and in most cases the chairman of a policy board. This follows from the fact that there should be consistency between the functions of the governor as chief executive officer and the necessary authority to ensure that realistic targets be set. In the case of pure supervisory 
Table 5. Number of Members in Different Boards, end-2003

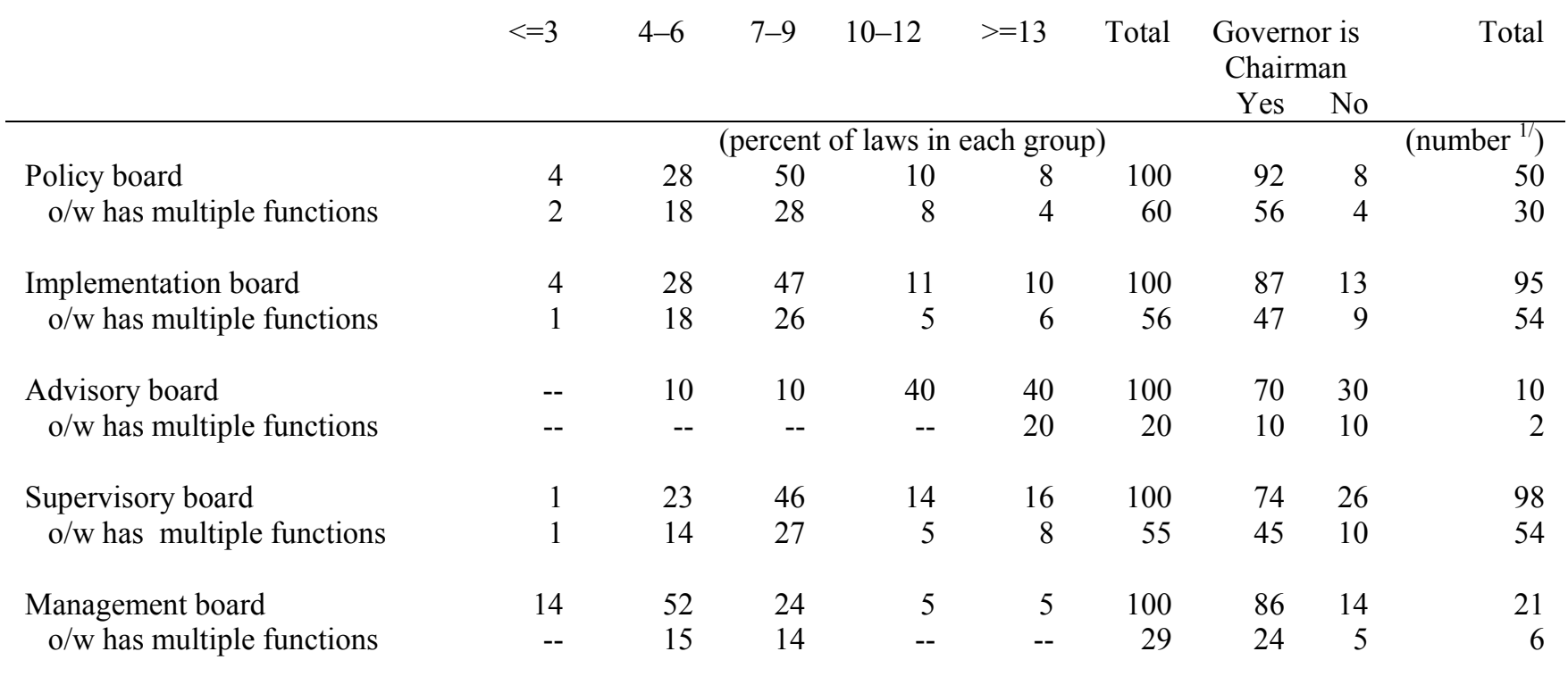

Source: Selected central bank laws. Information on the classification of individual countries can be requested from the authors of this paper.

Note: Certain functions may be performed by several governing bodies, but only the body with the primary responsibility is included in this survey. Figures may not add up — for instance, if the supervisory function is performed by the governor. Percentage figures are rounded.

1/ Number of laws surveyed.

boards, the governor should not be chairman. ${ }^{25}$ The survey, however, reveals that in 74 percent of the cases, the governor is also chairman for the supervisory board. This could result in serious problems, as widely illustrated from commercial corporations when the chairman of the board is also the chief executive officer. The distinction between management and the oversight function of the governing bodies often becomes blurred. Accordingly, it is far from an optimal structure, but is related to the fact that these supervisory boards also may have other functions.

\section{Meeting Procedures}

\section{Voting rights}

It is often implied that decisions require a majority of the votes, but certain decisions may require a qualified majority. A quorum is usually stipulated in the law, and it is often

\footnotetext{
${ }^{25}$ In an interesting review of the literature on boards of corporations, Hemalin and Weisback (2001) discuss the conflicts within the board room between the chief executive officer (CEO) and a board with both internal and external members that oversees as well as hires and fires the CEO. They find that there is empirical evidence for higher CEO turnover in case of poor performance when the board comprises more external members.
} 
designed to require that nonexecutive directors be present. As discussed below, a government representative may be present to ensure coordination, but often does not and should not have voting rights in implementation boards. This is an issue in policy board but particularly in implementation boards to avoid recreating the inflation bias. In many countries, it appears that consensus and collective responsibility is an accepted practice. However, in practice, particularly if the governor is charismatic, this approach often means that the governor decides using the other board members mainly as advisors. ${ }^{26}$ The members are usually collectively liable for their decisions, and only if they insist on including their dissent in the minutes, will they not be liable. ${ }^{27}$ In our view, individual responsibility by all board members is an essential element of an autonomous and accountable central bank.

\section{Frequency of board meetings}

The meeting frequency of the various boards depends on their functions. Supervisory boards need less frequent meetings - say quarterly and when needed. Policy boards providing guidance for the overall directions of the monetary policy may meet quarterly or monthly, but the latter if it also functions as an implementation board, taking decisions on how to execute the target. Management boards often meet weekly or every fortnight. In Paraguay, for instance, the board of directors makes implementation, management, and supervisory decisions and must meet at least weekly.

\section{Minutes}

Practices vary regarding publication of minutes. In some laws it is explicitly stipulated that minutes remain secret unless the board decides otherwise. In the case of goal autonomy, published minutes of board meetings of central banks may be required. Since there is no clearly defined primary objective, it is important to inform the general public about what currently is considered its most important objective. This, however, could also have an adverse impact, particularly if certain board members represent different regions or economic interests, since it may then become more difficult for such members to give priority to their fiduciary responsibilities instead of representing their constituency. In countries with target autonomy, the latter factor may outweigh the former, since the primary objective is already clearly defined. Accordingly, there may be less need to publish minutes as long as other pertinent information is reported in a transparent and timely manner. Nevertheless, King

\footnotetext{
26 The Federal Reserve System's Federal Open Market Committee (FOMC) adopts decisions by majority rule. Chappell, McGregor, and Vermilyea (2004) analyzed FOMC meetings during the period 1970-78 and found empirical evidence (page 421): “... that the Chairman carries greater policymaking weight than rank-and-file Committee members."

27 In Paraguay, for example, if a resolution contravenes legal provisions, members of the board of directors incur joint and several liability unless respective minutes record their dissident vote. In Peru, members of the board are individually and jointly responsible for decisions made with their participation, and the responsibility is removed only if within five days they give notice of their dissent to the President through a notary public. In the Philippines, board members are liable for any loss or injury as result of violation of law, negligence, abuse, malfeasance, misfeasance or failure to exercise "extraordinary" diligence.
} 
(2002), when discussing the experience with the Monetary Policy Committee of the Bank of England, finds that publishing minutes has been successful in creating a wider understanding of the issues discussed by the Committee.

\section{Composition of Boards}

The composition should ensure an informed and balanced view without conflicts of interests.

\section{Government representatives}

Clearly defined provisions with regard to central bank objectives, authority, and conflict resolution with the government should eliminate the need for direct government representatives on policy boards and especially on implementation boards. However, several central bank laws allow representatives from the government and in some cases the legislature to become board members. In most cases, however, only the minister of finance or a representative can participate in board meetings, and in almost half of these cases, this member does not have the right to vote (Table 6). In some countries, this representative has the right to postpone a vote to the next meeting, which is intended to resolve potential conflicts. Increasingly, central bank laws clearly stipulate that government officials cannot be board members with the right to vote, but that a representative of the minister of finance may participate in the meetings, with the view to ensure coordination of economic policies. ${ }^{28}$ This is particularly important for boards making decisions on how to implement the target.

As expected, government representatives on management boards (usually a full-time position) are rare unless the central bank has limited or diminished autonomy. Although government representation is usually marginally stronger in supervisory boards than in policy and implementation boards, the tendency is not as pronounced as expected. This seems to be caused by the fact that many supervisory boards also perform other functions.

Most central bank laws stipulate that the board comprise members ensuring a balanced view. Only a few laws explicitly stipulate that different sectors of the economy or regions be represented. In Botswana, for instance, a certain number of board members are to represent different sectors. Particularly in federal systems, such as those represented by Switzerland, Tanzania, and the United States, the law requires that different regions be represented —often by the various branches sending representatives. The same situation applies in the case of language differences, as in Belgium. This practice is also used in the case of advisory boards-Pakistan being a case in point. It is important that board members representing different constituencies are professional and are fully aware of their fiduciary responsibilities.

\footnotetext{
${ }^{28}$ Fujiwara (2003), for example, describes the proceedings of a monetary policy meeting at the Bank of Japan, including the role of government representatives. They can express views of the government and request that a decision be postponed to the next meeting of the Policy Board, but it is up to the Board to accept such a request.
} 
Table 6. Composition of Different Governing Bodies, end-2003

\begin{tabular}{|c|c|c|c|c|c|c|c|c|c|c|}
\hline & \multicolumn{4}{|c|}{ Government officials } & \multirow[t]{3}{*}{ Total } & \multicolumn{4}{|c|}{ Explicit requirement for } & \multirow[t]{3}{*}{ Total } \\
\hline & \multirow[t]{2}{*}{ No } & \multicolumn{2}{|c|}{$\begin{array}{l}\text { Ex officio: } \\
\text { Voting Rights }\end{array}$} & \multirow[t]{2}{*}{$\begin{array}{c}\text { Other } \\
\text { officials }\end{array}$} & & \multicolumn{2}{|c|}{$\begin{array}{c}\text { Sectoral } \\
\text { Repre- } \\
\text { sentation }\end{array}$} & \multicolumn{2}{|c|}{$\begin{array}{r}\text { Regional } \\
\text { Repre- } \\
\text { sentation }\end{array}$} & \\
\hline & & No & Yes & & & No & Yes & No & Yes & \\
\hline & \multicolumn{8}{|c|}{ (percent of laws in each group) } & \multicolumn{2}{|c|}{ (number ${ }^{1 /}$ ) } \\
\hline Policy board & $48^{2 /}$ & 6 & 24 & 22 & 100 & 92 & 8 & 92 & 8 & 50 \\
\hline Implementation board & $47^{3 /}$ & 11 & 16 & 26 & 100 & 93 & 7 & 93 & 7 & 94 \\
\hline Advisory board & 20 & 30 & -- & 50 & 100 & 40 & 60 & 70 & 30 & 10 \\
\hline Supervisory board & $344^{4}$ & 11 & 25 & 30 & 100 & 90 & 10 & 91 & 9 & 98 \\
\hline Management board & 71 & 19 & 5 & 5 & 100 & 95 & 5 & 95 & 5 & 21 \\
\hline
\end{tabular}

Source: Selected central bank laws. Information on the classification of individual countries can be requested from the authors of this paper.

1/ Number of laws surveyed.

2/ In seven of these countries, the minister of finance or another government representative may participate in the meetings, but is not formally a member of the board.

3/ In 12 of these countries, the minister of finance or another government representative may participate in the meetings, but is not formally a member of the board.

4/ In some of these countries, the minister of finance or another government representative may participate in the meetings, but is not formally a member of the board.

A few boards allow representatives of the bank's employees to participate, including Austria (two staff representatives at General Council to participate in negotiations on personnel, social and welfare matters), France (one staff member at General Council for a six-year term), and Norway (two members are elected by and from among the employees to supplement the Executive Board when matters of an administrative nature are discussed).

\section{Conflict of interest}

An increasing number of central bank laws, particularly newer ones with clearly defined autonomy, explicitly stipulate that the central bank is an autonomous institution not subject to directions from any other body and only will act according to the central bank law and pertinent regulations. However, several countries, when specifying a central bank's tasks and functions include a clause "and as determined by other laws." While it may be well-intended to grant authority to perform functions specified in other laws and ensure that the central bank observe the law, such a provision can also be used to request that the central bank perform quasi-fiscal and other activities outside its core functions, which should be avoided. It is therefore generally advisable to state that the central bank can perform tasks and functions designated by other laws, provided they are consistent with the central bank law. 
Historically, there have been several examples where the central bank board has had additional functions, such as being a board for other institutions. ${ }^{29}$ This practice is now less prominent, but several central bank laws do allow the governor or the deputies to participate on boards of state institutions, such as development banks, etc. Particularly if these institutions are supervised by the central bank, such members have a conflict of interest. More important is the problem of external board members potentially benefiting from insider information. ${ }^{30}$ This may be avoided if membership of a governing body making policy decisions is a full-time position and forbids membership on other boards of financial institutions. It is important that there be no question about the fiduciary responsibilities of directors and officers. Particularly in implementation boards, such as many of the newly established monetary policy committees, the need for specialist expertise and access to sensitive insider information, limit, in practice, nonexecutive members to representatives from academia or retirees with special expertise.

Furthermore, several laws include provisions preventing financial or familial conflict of interest. For instance, members cannot be a shareholder, director, manager, or an officer in banking or financial institutions, particularly if the central bank supervises these institutions. In Paraguay, for example, although banking supervision is performed by the Superintendency of Banks, board members may not have an interest in institutions overseen by the Superintendency because the central bank submits a list of candidates for the management of the Superintendency. ${ }^{31}$ Often these requirements are less rigorous for members of the supervisory board. However, for the governor and deputy governor, restrictions may also relate to the close family. Furthermore, several laws have provisions aimed at preventing nepotism - both avoiding too close a relationship with the appointer and too many closely related board members. ${ }^{32}$

${ }^{29}$ For instance, previously the board of directors of the Canadian central bank also functioned as the Board of the Industrial Development Bank, and in Australia, the Board of Directors of the Reserve Bank also functioned as the Board for a trading bank and a savings bank.

30 This has remained a problem for boards having external directors. It was, for instance discussed by the Parker Tribunal in 1958 regarding allegations that bankers participating in the Court of the Bank of England had insider information, when the Bank Rate was changed. For details, see Aufricht (1965), chapter 4, footnote 70. Until recently, representatives from state-owned banks participated in the board of the Egyptian central bank.

31 In Peru, for instance, holders of more than 5 percent of the capital or net worth of financial institutions cannot be appointed directors of the board. In some other countries the limit is 10 percent, or not a "substantial interest" in any private bank, as in the Philippines. A few countries, such as Spain, allow the governor and other board members to temporarily divest themselves from these interests by delegating the management of such interests to a trustee with clear instructions on how to manage these funds. Some countries, to enforce these provisions, require that members of governing bodies must declare their financial condition. In Peru, for instance, members of the board must make a statement of their assets and income under oath, before taking office and 30 days before leaving office.

32 In Nicaragua, for instance, the governor must not be related to the president and the other board members must not be related to the governor and President. In Bolivia, for example, members of the same family up to the third degree of consanguinity and the second degree of affinity may not be members of the Board. In Peru, two or more relatives within the fourth degree of consanguinity and second degree of affinity, as well as married couples, cannot be appointed as directors. 
Some countries have introduced explicit restrictions on membership in political partiesparticularly countries that previously had a one-party system. Some laws stipulate that a director of the board cannot be a member of a political party, as in Romania, or cannot be a member or an official of a political party, as in Nepal. It has been questioned if this impinges on the members' civil liberties. Instead of prohibiting membership in a party, some laws require that members of governing bodies - particularly the governor and deputy governors - not play a leading role in a political party. In Paraguay, for instance, the members of the board of directors must not engage in activities of a partisan political nature or occupy a managerial position in a union or political organization. In Armenia, board members cannot also function as managers of any "public-political organization."

\section{E. Nomination, Appointment, and Dismissal}

Nomination, appointment, and dismissal procedures for members of the governing bodies are particularly important for entrenching the autonomy of the central bank as well as ensuring the integrity of central bank officials. A distinction can usually be made between the governor, ex officio members, and other members of the respective governing bodies.

\section{Qualification requirements}

Members of the governing bodies are usually subject to a range of qualification requirements. They may refer to professional skills, such as experience in banking, finance, economics, or law, and, in a few cases, accounting, auditing or international trade (for instance, in Colombia). In some countries, particularly in transition economies, it is explicitly stipulated that the governor, and occasionally the deputy governors, must have practical experience in one of these areas for a specified time period. Several countries have age limits for the governor and deputy governor, and occasionally for other board members. ${ }^{33}$ Many laws explicitly require that members of governing bodies have citizenship in the respective countries. $^{34}$

\footnotetext{
${ }^{33}$ In Cape Verde, for instance, the governor must have at least eight years of professional experience and the remaining board members six years. In Venezuela, the governor must be over 30 years of age. In the Philippines, the governor must be 40 years and the other members of the Monetary Board must be at least 35 years old. In Namibia, board members must not be under the age of 21 or have attained the age of 65 when appointed. In Cambodia, board members shall not be more than 65 years of age. In Belgium, the term of members of the governing bodies shall generally expire when they reach 67 years of age, but they can, with the authorization of the minister of finance, complete their current term, but no one shall remain in office beyond the age of 70 years. In Papua New Guinea, the governor shall not hold office if 70 years or older. In some countries, particularly if central bankers are considered civil servants, details about age limit may be included in other legislation.

${ }^{34}$ An interesting exception was the first governor of the Central Bank of Bosnia and Herzegovina. Due to the difficult situation after the war, the law stipulated that the governor for the first term should not be a citizen of Bosnia and Herzegovina or one of the neighboring countries. Instead, the first governor was nominated by the IMF and appointed by the presidency of Bosnia and Herzegovina. (At the end of the governor's term, the authorities decided to give him citizenship and reappoint him.)
} 
In addition to professional qualification requirements there may be a general requirement to be fit and proper, which may be formulated as being of good moral standing (European Central Bank), have good moral character (Philippines), or unquestionable integrity (Philippines). Many laws elaborate further and include language such as the person cannot be convicted of a crime no longer subject to appeal or a conviction that cannot be converted to a fine, as in Botswana. Frequently it is required that a board member not have been declared bankrupt, which in some countries is modified by permitting a certain period of discharge. In Peru, for instance, incompatibilities include having pending tax obligations or not being registered as an income tax payer. In Bolivia, a person holding a matured or current obligation with financial institutions is disqualified. In practice, board members of central banks should, at a minimum, observe the fit and proper requirements for bank owners and bank managers.

\section{Nomination and appointment}

In selecting board members and other high officials, a double-veto arrangement is usually recommended - that is, one body nominates and another body appoints, provided these two bodies truly balance one another. This encourages appointment of qualified persons; however, it can also be used to create a stalemate. Therefore, a few countries with a double veto arrangement have also introduced time limits within which a new nomination must take place if the initial nominee is not appointed. In this survey, some type of double veto arrangement is in place for the appointment of about 60 percent of the governors (Table 7). The degree of autonomy does not appear to influence the use of the double veto arrangement. Regarding other board members, a double veto arrangement is in place in about half of the surveyed laws - although less for supervisory boards (Table 8). In these tables, the appointer is the body having the final say regarding the appointment.

There are different ways to depoliticize the appointment process. In some countries, the nominator, which may be a special committee as in Nepal, in nominating the governor, produces a list with - often about three - qualified candidates, as in the Netherlands. In several countries, the governor nominates certain members-particularly the deputy governor or members of management boards. This is useful to facilitate collaboration with the governor, but this practice should not be used if the board also has a supervisory function.

\section{Remuneration}

In commercial corporations, management and board members are frequently remunerated depending on profitability. However, when private sector economists were asked to rank seven factors important for central bank credibility, personal incentives for the governor was considered the least important (de Haan and others, 2004). Profit sharing is not a good practice for central bankers - whether directors, officers, or staff-since profit maximization is contradictory to maintaining price stability. Therefore, several laws explicitly stipulate that profitability is not an objective of the bank. Unfortunately, two of the surveyed central bank laws do allow profit sharing. 


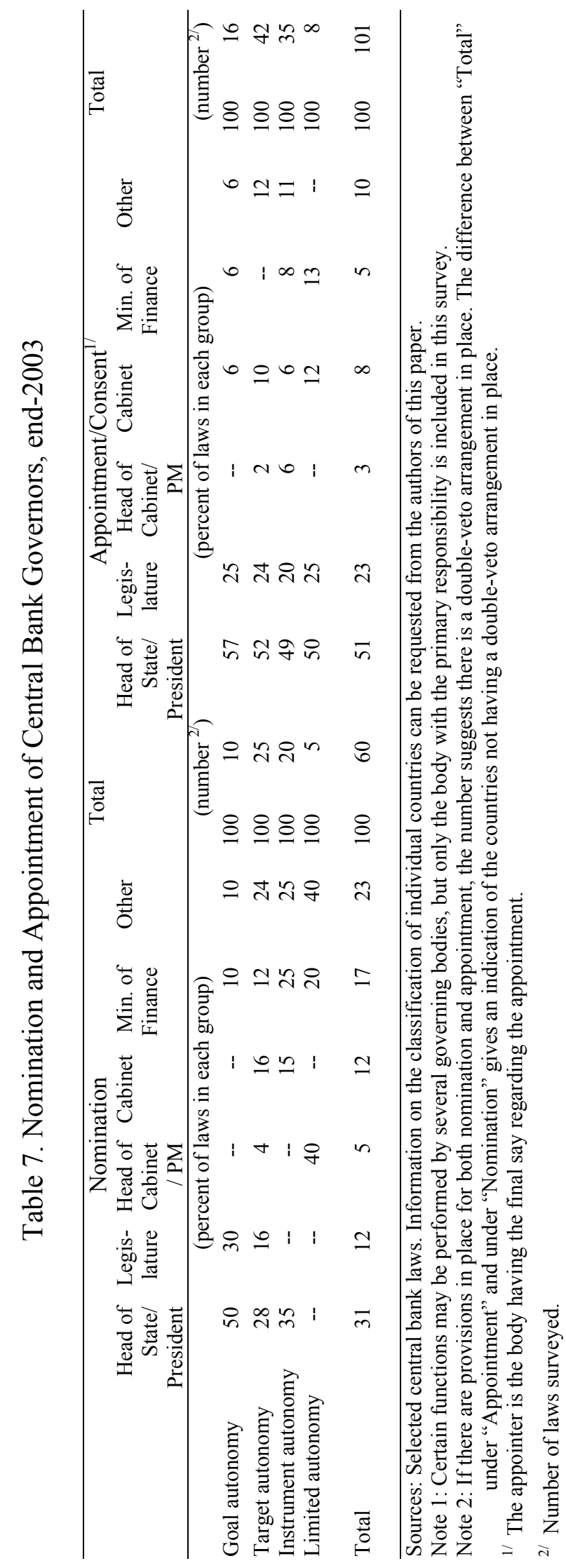




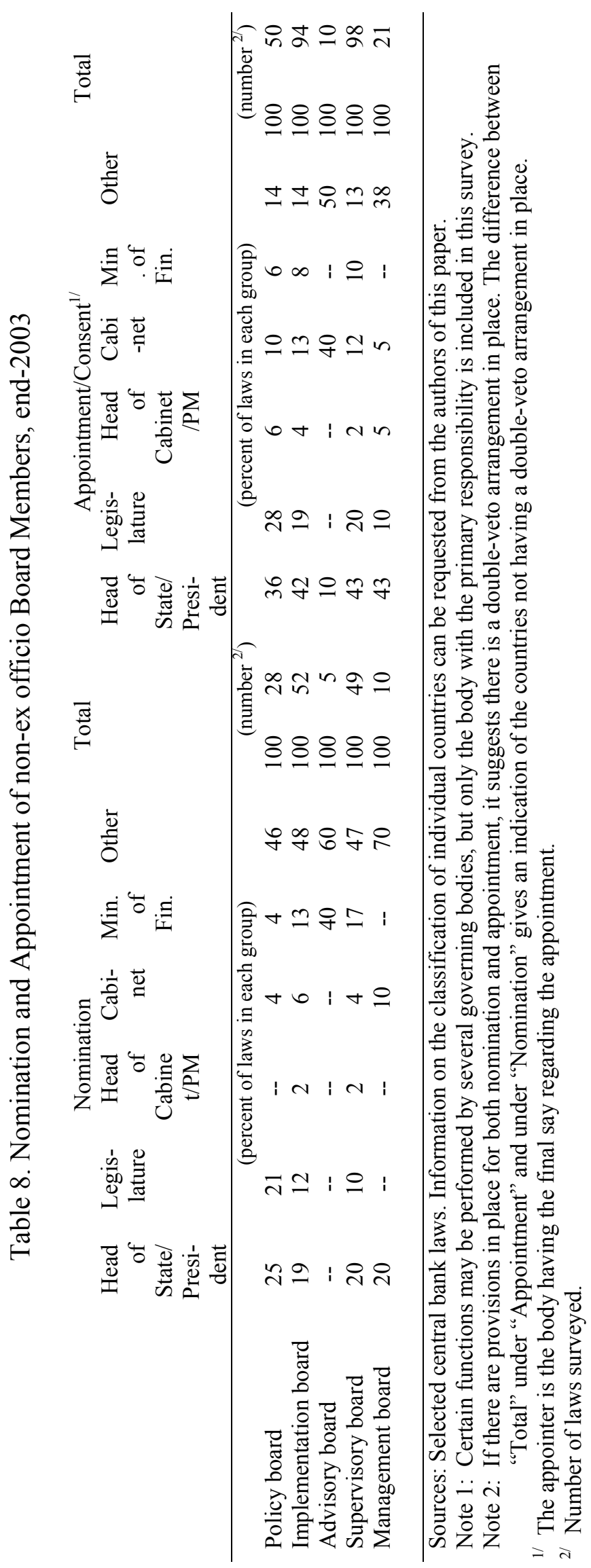


An alternative standard, measuring performance against the primary objective, is not practical. It is difficult to identify and quantify factors inside and outside the bank's control affecting the outcome. Furthermore, the directors and officers may determine their own target. Due to these difficulties, and the fact that reputational risk is an important parameter for most central bankers, performance-enhancing remuneration is generally not used for board members. Some central banks, however, do use performance bonuses for staff depending on their functions. Performance remuneration was discussed when the Law on the Reserve Bank of New Zealand of 1989 was drafted. It was decided to instead allow the minister of finance to dismiss the governor in case the inflation target was breached. Performance is, of course, an issue in the case of reappointments.

It is usually recommended that central bankers be paid a salary related to the level offered by the private sector. If a board determines the salary, unless it clearly functions only as a supervisory board, it may be useful that the government be given the right to veto the salary. However, to avoid undue influence, a provision that the remuneration not be changed to the member's disadvantage during the term is useful. ${ }^{35}$

\section{Legal immunity}

Legal immunity against claims for actions taken in good faith has become good practice for central bankers and is included in many standards, such as the Core Principles for Effective Banking Supervision (Delston, 1999). In the Bahamas, for instance, no action, suit, prosecution or other proceedings may be brought or instituted personally against any directors in respect of any bona fide action in pursuance of the central bank law. In a few laws, however, instead of protection against actions taken in good faith, the law specifies liability exists for certain actions, such as decisions breaching legal provisions. In Australia, members of the Bank Board are liable and must observe the obligations specified in the Companies Act.

\section{Removal and dismissal}

Protection against arbitrary dismissal of members of governing bodies is another key element in ensuring central bank autonomy and is a standard component of indexes measuring central bank autonomy. Most central banks have such provisions, although they are not always fully satisfactory. A breach of qualification requirements during the term usually results in dismissal. Laws also allow dismissal in case of serious misconduct or gross negligence. In

\footnotetext{
35 Practice varies significantly among countries. In Australia, the members of the Reserve Bank Board are paid such remuneration as determined by the Remuneration Tribunal subject to the Remuneration Tribunal Act of 1973. In Papua New Guinea, salary allowances and benefits for the governor are fixed by the national parliament following considerations of the Salaries and Remuneration Commission, which is mentioned in the constitution. In Fiji, the salary of the governor is set from time to time by the Higher Salaries Commission. One central bank law stipulates that fees for board members should be comparable with central banks in the region, but it is not clear if this provision is observed. In the Philippines, the remuneration of the Governor and non-ex officio members is fixed by the President of the Philippines at a sum commensurate to the importance and responsibility of the position. In Kuwait, the governors' salary is fixed by Council of Ministers on recommendation of the Ministry of Finance.
} 
some countries, board members can be dismissed if significantly harming the interests of the bank. The other members of the board usually play an important role in assessing such incidents. In a few cases this may be delegated to a special tribunal, or left to the highest court, provided the judicial system is truly independent. Another safeguard is to require a dismissal be approved by the legislature, which will allow the general public to be informed if the president, cabinet, or minister of finance tries to exert undue influence on the central bank. In Peru, for instance, members of the board can only be dismissed in case of a crime or serious misconduct and the resolution must be adopted by two-thirds of the members of the Congress. Since dismissal should be difficult, the nomination and appointment procedures are particularly important.

\section{F. Terms of Selected Board Members}

The term for titular members of boards is fixed in most central bank laws. It is generally recommended to have terms longer than the term of the body with the predominant influence on the appointment. This reduces the risk for undue influence because of concerns regarding reappointment. The term of the governor is in most cases fixed and in many cases longer than the term of the other non-ex officio members. The survey finds that if the term is fixed, it is often around five years (Table 9).

Table 9. Terms of Different Central Bank Boards of non-ex officio Members, end-2003

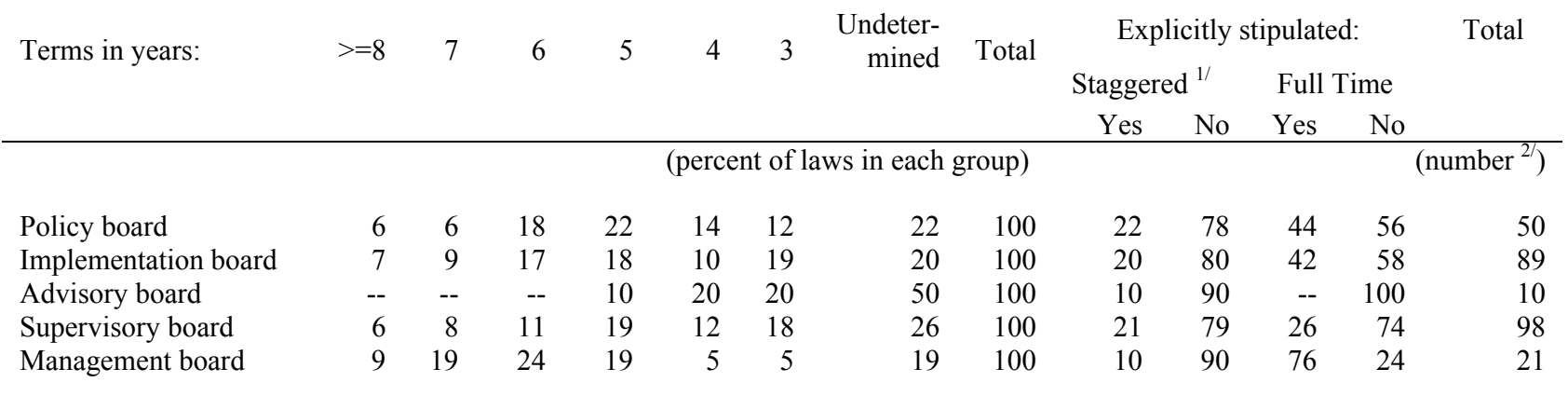

Source: Selected central bank laws. Information on the classification of individual countries can be requested from the authors of this paper.

Note: Terms of governors, which may differ from non-exofficio members, are not included in this table. Certain functions may be performed by several governing bodies, but only the body with the primary responsibility is included in this survey.

1/ Although terms may not be explicitly staggered, occasional vacancies may in practice result in staggered terms.

${ }^{2 /}$ Number of laws surveyed.

The term is usually a little longer for management boards and shorter for advisory boards. The members of the Board of Governors in the Federal Reserve System of the United States, which consists of seven members, have unusually long terms. They are appointed by the President with advice and consent of the Senate for a term of 14 years. The chairman is designated by the President with the consent of the Senate for a term of four years. Long terms, in principle, require stricter provisions regarding dismissal for gross misconduct and negligence. Some central bank boards have terms of three years or shorter. Relatively few central banks do not specify a term. In some of those cases, the governor may in effect have 
an unlimited term. ${ }^{36}$ This makes it particularly important that the person can be removed in the event of gross misconduct.

\section{Vacancies and staggered terms}

It is also considered good practice to have staggered terms to ensure continuity. This is explicitly required in about 20 percent of the surveyed laws, with the exclusion of management and advisory boards. Staggered terms usually require that if a position becomes vacant during the term, a new appointment only lasts for the remaining period of the term. If staggered terms are not explicit, a new appointment is often for a new full term. This may result in some degree of continuity, since positions occasionally become vacant during a term. A few laws stipulate a period within which a vacancy shall be filled with a view to ensure a quorum.

\section{Subsequent service}

Relatively few, but mainly newer, central bank laws include provisions regarding subsequent service, such as Spain and the Philippines. In most of these cases, the restrictions only cover the governor and deputy governors or they are less rigorous for other board members, depending on the role of the board. In the Philippines, no member of the Monetary Board may be employed in a bank or financial institution within two years after the term has expired, except as an official representative. In Rwanda and Spain, the law also addresses the remuneration during this period. In some countries, similar requirements may be covered by other legislation or rules governing central bank officers, particularly if they are considered civil servants.

\section{Conclusion}

Good central bank governance means that objectives, tasks, and functions delegated to the central bank are achieved effectively and efficiently. It is now generally accepted that central banks should have clearly defined and prioritized objectives; be given sufficient authority and autonomy to achieve their objectives, tasks, and functions; and be held accountable to ensure checks and balances. Figure 3 illustrates that a legal framework ensuring consistency between autonomy, authority, and accountability constitutes a balanced base on which a central bank can accomplish its objective(s), tasks, and functions. Good governance is the bond that keeps the different elements of autonomy, authority, and accountability together.

There is less consensus regarding the type of autonomy to be delegated to the central bank. This is in part due to the fact there is not yet a full appreciation of the different premises for autonomy, which is affected by a range of different country specific factors, such as degree of economic and financial sector development, history, as well as political system and legal

\footnotetext{
${ }^{36}$ In Denmark, for instance, the terms of office of the members of the Board of Governors are indefinite, but they are required to retire at the age of 70 years. A former chairman of the Board of Governors was in office from 1965 to end-1994.
} 
Figure 3. Illustration of a Consistent Central Bank Law

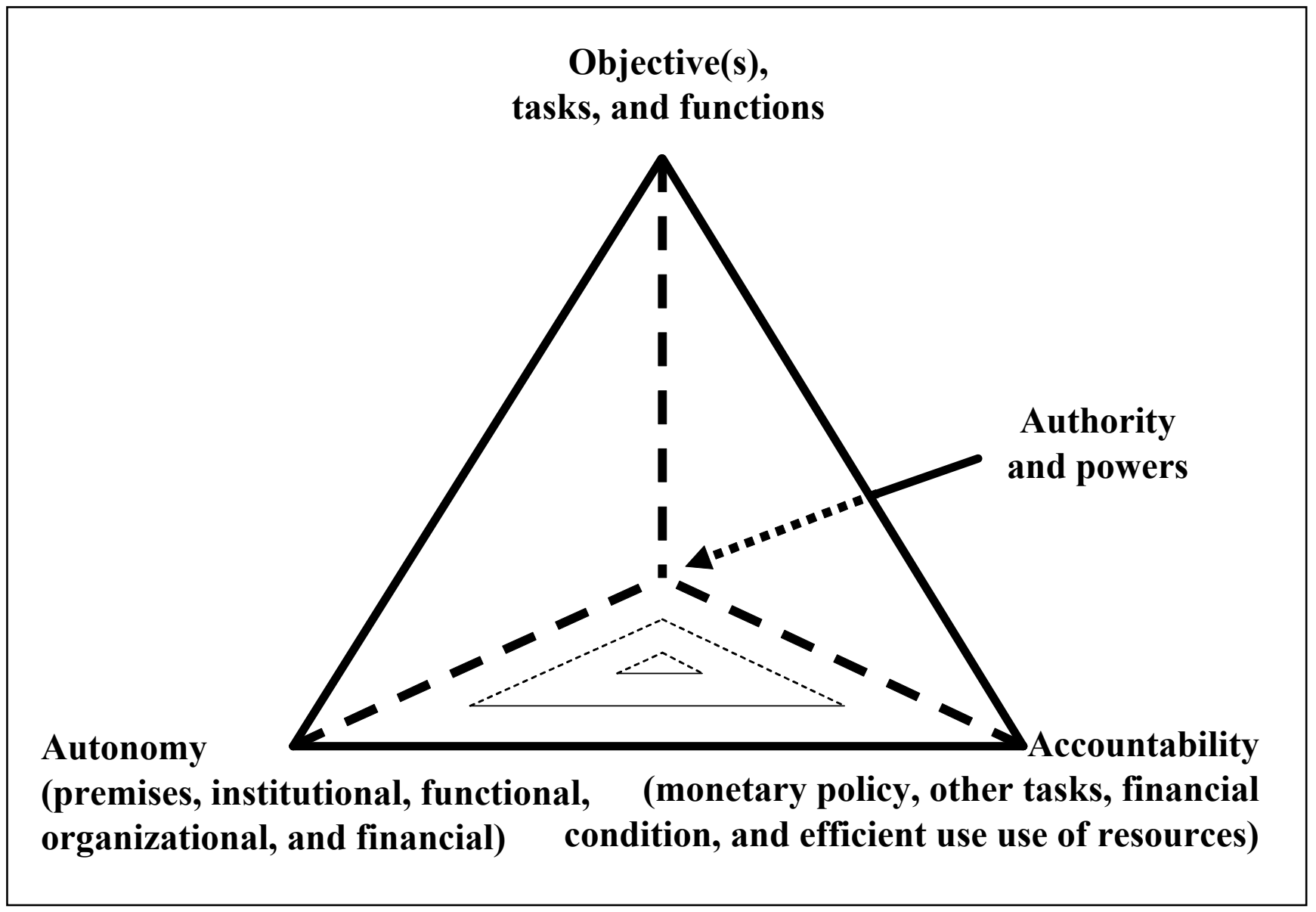

traditions. All these factors influence the design of the governing bodies of a central bank, which is only one vital element for ensuring good governance and entrenching autonomy.

The design of the governing boards and management included in this survey of 101 central bank laws, covering 113 countries, demonstrated that there are many different ways to design an adequate structure. About 63 percent of the surveyed laws have one board, while others have two or more boards. In 78 percent of the surveyed laws, the governor has the sole responsibility for the management of the bank, while in the other countries a management board exists.

Issues to consider when designing the governance structure for a central bank were considered. The empirical findings only partially supported the a priori expectations following from the analytical framework. This is due to the fact that many governing bodies have several different functions, which makes the evidence imprecise. Furthermore, the actual governance structure and practices that have developed may not always fully reflect the de jure structure. Unfortunately, there are also examples where the law supports a good 
governance structure but is not obeyed. Finally, it is our perception that the governance structure in a number of countries may be lagging the trend toward central bank autonomy and accountability.

Nevertheless, this paper has identified a range of issues to consider when designing the structure, size, and composition of the governing bodies and management of a central bank:

- The governance structure of a central bank must acknowledge the type of autonomy delegated to it. It is useful to make a distinction between, respectively, goal autonomy, target autonomy, instrument autonomy, and limited or no autonomy, since it helps define the functions of the respective governing boards and management. In addition, a range of country specific factors, including economic development (preference for price stability), history, political system (importance of election cycles), and judicial traditions (particularly corporate law and the rule of law) must also be given due consideration. Then the number of bodies, their size, and composition can be determined with a view to ensure an informed, balanced, and professional view without conflicts of interest. In short, it is important to remember that one size does not fit all.

- A simple board structure may imply a complicated board composition and vice versa. If one body has a range of overlapping functions, it may need to be larger and its composition becomes more complicated. A small board (even one person) is often more decisive with less risk of diluting responsibilities and requires a smaller pool of potential candidates, but it also delegates substantial responsibility to very few people.

- Policy boards must be sufficiently broad to ensure an informed, balanced, and professional view, whether with regard to members' education or experience from different sectors or regions, while at the same time ensuring that the size does not impede the effectiveness. With a view to avoiding conflicts of interest, members may be executives or full-time directors of the central bank. However, to ensure a balanced view, alleviate concerns about central banks being too conservative, and to a lesser extent to address a perceived democratic deficit, outside members with special expertise should also be considered. If such a board only comprises internal members, whose career depends on the governor, it is not apparent that these members will give priority to their fiduciary responsibilities. It may thus be useful to have qualified nonexecutive directors, such as experts from academia or business, provided the autonomy of the central bank is not encroached.

- Boards responsible for implementing target(s) should comprise highly qualified members, as the implementation is mainly a technical matter. To avoid conflicts of interest, such a board should generally comprise full-time directors. However, even in this case, depending on the country specific conditions, consideration could be given to include external members provided the autonomy of the bank is not encroached. Government representatives with voting rights should not participate in a 
board deciding how to implement a target, but can participate with a view to ensure coordination without the right to vote.

- The majority of a board primarily responsible for supervising the central bank should constitute nonexecutive members, or outside individuals. Provided the autonomy of the central bank is not adversely affected, government representatives on supervisory boards are more acceptable.

- The governor should not be the chairman of a pure supervisory board, but be obliged to be present at meetings of the supervisory board to be available to answer questions. There should be a clear separation of duties. If the board also has other functions, however, the governor will usually be chairman.

- The respective responsibilities of all governing bodies and management, including their fiduciary objectives, should be clearly defined in the law. This is particularly important for a body having overlapping functions, especially if the same body has responsibility for implementing policies and overseeing their implementation, it can become quite complicated.

- The use of committees can achieve several objectives, but it is important that their use does not dilute the responsibilities of the governing bodies. Monetary policy committees, for instance, may be used as an avenue to include external members to ensure a balanced view, while at the same time separating monetary policy decisions, depending on the committees' authority, from the authority of the board and management. Audit committees can result in more attention being given to financial conditions, but if a central bank already has an appropriately designed supervisory board, an audit committee may not be necessary. However, if there is only one board, which primarily is a policy board, it may be particularly useful to delegate some oversight functions to an audit committee with a chairman, who is a nonexecutive member of the board, with the other members being nonexecutive directors or external experts not being board members.

- Similar to commercial enterprises, a consistently designed governing and management structure can facilitate good governance, but good governance will only be achieved if the directors and officers are persons of great integrity, able, and willing to live up to their fiduciary responsibilities. For central banks, the nomination and appointment procedures, together with appropriate safeguards against undue influence, are likely to be more important for good governance and performance than incentives that may move priorities from fiduciary responsibilities to personal motives, as evidenced by recent corporate scandals in several industrialized countries. 


\section{REFERENCES}

Abrams, Richard K, and Michael W. Taylor, 2000, "Issues in the Unification of Financial Sector Supervision,” IMF Working Paper 00/213 (Washington: International Monetary Fund).

Alesina, Alberto, and Lawrence H. Summers, 1993, "Central Bank Independence and Macroeconomic Performance: Some Comparative Evidence," Journal of Money, Credit, and Banking, Vol. 25 (May), pp. 151-62.

Anyadike-Danes, M.K., 1995, "Comments on Measuring the Independence of Central Banks and Its Effect on Policy Outcomes by Cukierman, Webb, and Neyapati," The World Bank Economic Review, Vol. 9, No. 2, pp. 335-40.

Amtenbrink, Fabian, 1999, The Democratic Accountability of Central Banks (Portland, Oregon and Oxford: Hart Publishing).

Aufricht, Hans, 1965, Comparative Survey of Central Bank Law (New York: Praeger).

Basel Committee on Banking Supervision, 1999, Enhancing Corporate Governance for Banking Organizations (Basel: Bank for International Settlements), September.

Berger, Helge, Jacob de Haan, and Sylvester C.W. Eijfinger, 2000, “Central Bank Independence: An Update of Theory and Evidence,” Discussion Paper No. 2353 (London: Centre for Economic Policy Research).

Blinder, Allan S., 2004, The Quiet Revolution: Central Banking Goes Modern (Yale University Press).

— Analysis of Group vs. Individual Decisionmaking," NBER Working Paper Series No. 7909 (Cambridge: National Bureau of Economic Research).

—, 1998, Central Banking in Theory and Practice (Cambridge: MIT Press).

Branson, Douglas, 2001, “The Very Uncertain Prospect of 'Global' Convergence in Corporate Governance,” Cornell International Law Journal, Vol. 34, No, 2, pp. 321-62.

Buiter, Willem H., 1981, "The Superiority of Contingent Rules over Fixed Rules in Models with Rational Expectations," The Economic Journal, Vol. 91 (September), pp. 647-70.

Capie, Forrest, and others, 1994, The Future of Central Banking (New York: Cambridge University Press). 
Cecchetti, Stephen G., and Stefan Krause, 2002, "Central Bank Structure, Policy Efficiency, and Macroeconomic Performance: Exploring Empirical Relationships," Review of the Federal Reserve Bank of St. Louis, Vol. 84 (July/August), pp. 47-59.

Chappell Jr., Henry W., Rob Roy McGregor, and Todd Vermilyea, 2004, "Majority Rule, Consensus Building, and the Power of the Chairman: Arthur Burns and the FOMC," Journal of Money, Credit, and Banking, Vol. 36 (June), pp. 407-22.

Chortareas, Georgios, David Stasavage, and Gabriel Sterne, 2002, "Monetary Policy Transparency, Inflation and the Sacrifice Ratio," International Journal of Finance and Economics, Vol. 7, pp. 141-55.

Cottarelli, Carlo, and Curzio Giannini, 1997, Credibility Without Rules? Monetary Frameworks in the Post-Bretton Woods Era, Occasional Paper No. 154 (Washington: International Monetary Fund).

_ 1994, "Should an 'Independent' Central Bank Control Foreign Exchange Policy?" chapter 12 in Frameworks for Monetary Stability, ed. by Tomás J.T. Baliño and Carlo Cottarelli (Washington: International Monetary Fund).

Cukierman, Alex, 2002, "Does a Higher Sacrifice Ratio Mean that Central Bank Independence is Excessive?" Annals of Economics and Finance, Vol. 3, pp.1-25.

— 1994, "Central Bank Independence and Monetary Control," The Economic Journal, November, pp. 1437-48.

— 1992, Central Bank Strategy, Credibility, and Independence: Theory and Evidence, (Cambridge: MIT Press).

Cukierman, Alex, Geoffrey Miller and Bilin Neyapti, 2001, "Central Bank Reform, Liberalization and Inflation in Transition Economies-An International Perspective," Discussion Paper Series No. 2808 (London: Centre for Economic Policy Research).

de Haan, Jacob, Fabian Amtenbrink, and Sandra Waller, 2004, "The Transparency and Credibility of the European Central Bank," Journal of Common Market Studies, Vol. 42 (November), pp.775-95.

— Evidence for Developing Countries Using a New Indicator," Journal of Banking and Finance, No. 24, pp. 643-64.

de Jager, Johann, 2004, "Shareholder Activism in the South African Reserve Bank: A Blessing or A Course," Financial Services Board Bulletin, First Quarter. Available on: www.fsb.co.za. 
de Jong, Eelke, 2002, "Why are Price Stability and Statutory Independence of Central Banks Negatively Correlated? The Role of Culture," European Journal of Political Economy, Vol. 18, pp. 675-94.

de Koch, M. H., 1954, Central Banking (London: Staples Press).

Daunfeldt, Sven-Olov, and Xavier de Luna, 2003, Central Bank Independence and Price Stability: Evidence from 23 OECD-countries (Umeå: the Swedish Research Institute of Trade, Department of Statistics, Umeå University).

Debelle, Guy, and Stanley Fischer, 1994, "How Independent Should a Central Bank Be?" in Goals, Guidelines, and Constraints Facing Monetary Policy, Conference Series No.38, ed. by Jeffrey C. Fuhrer, Federal Reserve Bank of Boston, pp. 195-221.

Delston, Ross S., 1999, "Statutory Protections for Banking Supervisors," Financial Sector Website Paper No. 4, (Washington: World Bank). Available on: www1.worldbank.org/finance/html/statutory_protection.html.

Eggertsson, Gauti and Eric Le Borgne, 2003, “A Political Agency Theory of Central Bank Independence,” IMF Working Paper No. 03/144, (Washington: International Monetary Fund).

European Monetary Institute, 1998, Convergence Report 1998, European Monetary Institute. Available on: www.ecb.int/pub/pdf/othemi/englishen.pdf.

European Central Bank, 2004, Convergence Report 2004, European Central Bank, Frankfurt, available on: www.ecb.int/pub/pdf/conrep/cr2004en.pdf.

Fischer, Stanley, 1995a, “Central Bank Independence Revisited," American Economic Review, Papers and Proceedings (May), pp. 201-06.

_ 1995 b, "Modern Approaches to Central Banking," National Bureau of Economic Research Working Papers, No. 5064 (Cambridge: National Bureau of Economic Research).

Fry, J. Maxwell, 1998, “Assessing Central Bank Independence in Developing Countries: Do Actions Speak Louder than Words?” Oxford Economic Papers, July, pp. 512-29.

— D. Julius, L. Mahadeva, S. Roger, and G. Sterne, 2000, "Key Issues in the Choice of Monetary Policy Framework," in Monetary Policy Frameworks in a Global Context, ed. by L. Mahadeva and G. Sterne (London: Routledge).

Fujiwara, Sakuya, 2003, Inside a Monetary Policy Meeting, Speech given at Toyo University on March 13, 2003. Available on: www.boj.or.jp/en/press/04/press f.htm. 
Grilli, Vittorio, Donato Masciandaro, and Guido Tabellini, 1991, "Political and Monetary Institutions and Public Financial Policies in Industrial Countries" in Economic Policy: A European Forum, Vol. 6, October pp. 342-91.

Gutiérrez, Eva, 2003, "Inflation Performance and Constitutional Central Bank Independence: Evidence from Latin America and the Caribbean," IMF Working Paper No. 03/53 (Washington: International Monetary Fund).

Hermalin, Benjamin E. and Michael S. Weisbach, 2001, "Boards of Directors as an Endogenously Determined Institution: A survey of the Economic Litterature," NBER Working Paper Series No. 8161 (Cambridge: National Bureau of Economic Research).

Hopt, Klaus J., and others, eds., 1998, Comparative Corporate Governance-The State of the Art and Emerging Research, (Oxford: Clarendon Press).

Hüpkes, Eva; Marc Quintyn, and Michael W. Taylor, forthcoming, "The Accountability of Financial Sector Supervisors," IMF Working Paper (Washington: International Monetary Fund).

International Monetary Fund, 1999, Code of Good Practices on Transparency in Monetary and Financial Policies, approved by the IMF Executive Board on July 24 (see http://www.imf.org/external/np/mae/mft).

Ize, Alain, forthcoming, "Recapitalizing Central Banks: A Net Worth Approach," IMF Working Paper (Washington: International Monetary Fund).

Jácome, Luis I. H. and Francisco Vázquez, forthcoming, "Is There Any Link between Legal Central Bank Independence and Inflation in Latin America and the Caribbean?" IMF Working Paper (Washington: International Monetary Fund).

King, Mervin, 2002, The Monetary Policy Committee: Five Years On, Speech, given on May 22. Available on: www.bankofengland.co.uk/pressreleases/2002/063.htm.

Kydland, F. E., and E. C. Prescott, 1977, "Rules Rather than Discretion: the Inconsistency of Optimal Plans," Journal of Political Economy, Vol. 85, No. 3 (June), pp. 473-92.

Leblanc, Richard, and James Gillies, 2003, "The Coming Revolution in Corporate Governance," Ivey Business Journal, (University of Western Ontario).

Lepper, Jonathan, and Gabriel Sterne, 2002, "Parliamentary Scrutiny of Central Banks in the Untied Kingdom and Overseas," Quarterly Bulletin (London: Bank of England).

Loungani, Prakash and Nathan Sheets, 1997, "Central Bank Independence, Inflation, and Growth in Transition Economies," Journal of Money, Credit, and Banking, Vol.29, No.3 (August), pp. 381-99. 
Lybek, T., 1999, "Central Bank Autonomy, and Inflation and Output Performance in the Baltic States, Russia, and other Countries of the Former Soviet Union, 1995-97," IMF Working Paper No. 99/4 (Washington: International Monetary Fund).

_ 1998 , "Elements of Central Bank: Autonomy and Accountability," Monetary and Exchange Affairs Department Operational Paper No. 98/1 (Washington: International Monetary Fund).

Macey, Jonathan R. and Maureen O'Hara, 2003, "The Corporate Governance of Banks," Economic Policy Review, Federal Reserve Bank of New York, New York (April), pp. 91-107.

Maliszewski, Woljciech S., 2000, "Central Bank Independence in Transition Economies," Economics of Transition, Vol. 8, pp. 749-89.

Maloney, John, Andrew C. Pickering, and Kaddour Hadri, 2003, "Political Business Cycles and Central Bank Independence,” The Economic Journal, Vol. 113 (March), pp. C167-81.

Mangano, Gabriel, 1998, "Measuring Central Bank Independence: A Tale of Subjectivity and of Its Consequences," Oxford Economic Papers, Vol. 50 (July), pp.468-92.

Martínez-Resano, J. Ramón, 2004, “Central Bank Financial Independence,” Documento Ocasional No. 0401, Banco de España. Available on: www.bde.es/informes/be/ocasional/do0401e.pdf.

Mester, Loretta J., 2003, “Applying Efficiency Measurement Techniques to Central Banks, Working Paper No. 03-13, Research Department of the Federal Reserve Bank of Philadelphia. Available on: www.phil.frb.org/files/wps/2003/wp03-13.pdf.

Moser, Peter, 1999, "Checks and Balances, and the Supply of Central Bank Independence," European Economic Review, Vol. 43, pp. 1569-93.

OECD, 1999, OECD Principles of Corporate Governance (Paris).

— 1998, Management Control in Modern Government Administration: Some Comparative Practices (Paris).

Oosterloo, Sander, and Jakob de Haan, A Survey of Institutional Frameworks for Financial Stability, Occasional Studies, Vol. 1 (No.4), De Nederlandsche Bank. Available on: www.dnb.nl.

Persson, Torsten and Guido Tabellini, 1993, "Designing Institutions for Monetary Stability," Carnegie-Rochester Conference Series on Public Policy (December), pp. 279-310. 
Piketty, Thomas, 1999, "The Information-Aggregation Approach to Political Institutions," European Economic Review, Vol. 43, pp. 791-800.

Posen, Adam, 1995, "Declarations Are Not Enough: Financial Sector Sources of Central Bank Independence," in NBER Macroeconomics Annual, ed. by B. Bernanke and J. Rotenberg (Cambridge: MIT Press).

PriceWaterhouseCoopers, 1999, Audit Committees: Good Practice for Meeting Market Expectations. Available on: www.pwcglopbal.com.

Quintyn, Marc, and Michael W. Taylor, 2003, Regulatory and Supervisory Independence and Financial Stability, CESifo Economic Studies, Vol. 49. Available on: www.cesifoeconomic-studies.de.

Rogoff, Kenworth, 1985, “The Optimal Degree of Commitment to an Intermediate Monetary Target," Quarterly Journal of Economics, Vol. C, (November), pp. 1169-90.

Romer, Christina D. and David H. Romer, 1997, "Institutions for Monetary Stability," chapter eight in Reducing Inflation: Motivation and Strategy, National Bureau of Economic Research (Chicago: The University of Chicago Press), pp. 307-29.

Schiffman, Henry, 2004, "Good Governance for Central Banks," Central Banking (London: Central Banking Publications Ltd.) (August), pp. 42-6.

Schuler, Kurt, 1996, Should Developing Countries Have Central Banks? Institute of Economic Affairs (Baltimore: Johns Hopkins University).

Spiegel, Mark M., 1998, “Central Bank Independence and Inflation Expectations: Evidence from British Index-Linked Gilts," Economic Review, No. 1, Federal Reserve Bank of San Francisco.

Stella, Peter, 2003, "Why Central Banks Need Financial Strength,” Central Banking (London: Central Banking Publications Ltd.) (November), pp. 23-9.

Sullivan, Kenneth Roy, 2003, "Profits, Dividends and Capital-Considerations for Central Banks," in Accounting Standards for Central Banks, ed. by Neil Courtis and Benedict Mander (London: Central Banking Publications, Ltd.).

— 2000, "Transparency in Central Bank Financial Statement Disclosures," IMF Working Paper 03/76 (Washington: International Monetary Fund).

Svensson, Lars S. O., 2001, Independent Review of the Operation of Monetary Policy in New Zealand: Report to the Minister of Finance. Available on the Reserve Bank of New Zealand's website: www.rbnz.govt.nz/monpol/review/indrevopmonpol.pdf. 
Tuladhar, Anita, forthcoming, "Governance of Inflation Targeting Central Banks," IMF Working Paper (Washington: International Monetary Fund).

Unakul, Snoh and Supachai Panitchpakdi, 1978, Role of Central Banks in Economic Development, paper prepared for the Twelfth SEANZA Central Banking Course, Bank of Thailand (Bangkok).

Walsh, Carl, 1995, “Optimal Contracts for Central Bankers," American Economic Review, Vol.1 (March), pp. 150-67.

Zilioli, Chiara, 2003, Accountability and Independence: Irreconcilable Values or Complementary Instruments for Democracy? The Specific Case of the European Central bank, Editions de L'Universite de Bruxelles, reprinted from Melanges en hommage a Jean-Victor Louis, edited by G. Vandersanden. 


\section{Main Guidelines on Central Bank Autonomy AND ACCOUnTAbility}

\begin{abstract}
Objectives Price stability, as the best contribution monetary policy can make to balanced sustainable growth, and targets is the preferable formulation for the primary objective. Consistent with this broad objective, a specific target—which could, for example, involve explicit inflation targets, maintenance of a fixed exchange rate, or monetary aggregate targets - should be established and published. These targets may be determined by the central bank (target autonomy); or determined by the government in agreement with the central bank (instrument autonomy). To facilitate accountability, the target(s) should be easy to monitor. Consideration should be given to explicit, but limited "escape clauses" in the face of significant exogenous shocks.
Monetary A central bank should determine and implement monetary policy to achieve its target. To this end, policy the central bank should have authority to determine quantities and interest rates on its own transactions without interference from the government.

Conflict resolution

A clear and open process should be established to resolve any policy conflict between the central bank and the government. Some of the aspects below (e.g., the nature of government representation on the board) are potential channels for such a resolution; another approach is to allow the government to direct or overrule the central bank, but such a power should be constrained, to avoid other than exceptional use. It should be absolutely clear to the executive, legislature, and the general public that responsibility for the results lies with the government, not the central bank, if the central bank is overruled, its advice ignored, or its effectiveness is significantly limited by government policies. This may require that both the government and the central bank publish a formal statement to that extent. For instance, in cases where international reserves decline to levels insufficient to conduct international transactions due to factors outside the central bank's control, it shall make recommendations to the government. If the government does not react within a specified period, the central bank should notify the general public that it temporarily cannot be held accountable for price stability due to factors outside its control.
\end{abstract}

Governor

Board

Credit to government

Nomination and appointment/confirmation of the governor should be by separate bodies to provide some measure of balance, bearing in mind the institutional framework. The term should be longer than the election cycle of the body with the predominant role in selecting the governor. Dismissal should be only for breaches of qualification requirements, or misconduct; lack of performance could also be grounds if clearly defined in terms of the primary objective and specific targets. The latter could be ruled upon according to a suitable and independent judicial procedure, and perhaps be with the consent of the legislature.

Composition of the board should ensure a reasonably well informed and balanced view, but avoid conflicts of interest. Precisely what is reasonable depends in part on the role of the board (decision-making, monitoring, or purely advisory), and whether it is a single or multiple board structure. The highest level board should include a majority of nonexecutive, non-government directors. Indeed, direct government representatives should be eliminated from a policy board and probably also from a monitoring board. If a government representative does participate in a policy board, it should at least be without the right to vote (though it might be with a limited, temporary veto power). As with the governor, nomination and appointment/confirmation should be by different bodies; terms should be longer than the election cycle of the main body in the appointment process, and should be staggered; and dismissal of board members should occur only for breaches of qualification requirements and misconduct, and on performance grounds only if clearly defined. The latter could be ruled upon according to a suitable and independent judicial procedure, and be with the other board members' prior consent.

If not prohibited, direct credit to the government should be carefully limited to what is consistent with monetary policy objectives and targets. For example, temporary advances and loans could be allowed only if: (i) they are explicitly limited to a small ratio of average recurrent revenue of preceding fiscal years (say, 5 percent); (ii) they bear a market-related interest rate; and ideally (iii) they are securitized by negotiable securities. The central bank should not underwrite and 
participate as a buyer in the primary market for government securities, except with noncompetitive bids and within the overall limit for credit to government. Indirect credit to the government, that is, buying outright existing government securities held by the market, or accepting them as collateral, should be guided by monetary policy objectives. The central bank should not finance quasi-fiscal activities.

Exchange Basic consistency needs to be ensured between the exchange rate and monetary policy. If rate policy exchange rate policy (including choice of regime) is not solely the responsibility of the central bank, the bank should nevertheless have sufficient authority to implement monetary policy within the constraint of exchange rate policy (e.g., in a fixed exchange rate regime, to support the exchange rate as the specific target of monetary policy), and should be the principal advisor on exchange rate policy issues (e.g., as to whether the current regime is most suitable for the fundamental price stability objective). In the event of a conflict with the government on exchange rate issues, the conflict resolution procedures as stated above should come into effect.

Financial The law should ensure that the central bank has sufficient financial autonomy to support policy conditions autonomy, but with matching financial accountability. Its budget should not be subject to normal annual appropriation procedures (but could be subject to a longer-term appropriation - e.g., on a cycle consistent with the term of the governor). Only realized net profits, after prudent provisioning by the central bank and appropriate allocations to general reserves, should be returned to the government. The government should ensure the solvency of the central bank by transferring interest bearing negotiable securities if the authorized capital is depleted. The body to which the central bank is accountable should be allowed to ask external auditors and the auditor general to review the central bank's accounts and procedures.

Publication Policy and financial accountability should be clearly established. The central bank should prepare and formal statements on monetary policy performance at, say, six-month intervals, without prior reporting approval by the government. Regardless of to whom the bank is directly accountable; these statements should be forwarded to both the executive and the legislature and should be published for the benefit of the public. Annual financial statements audited by external auditors should similarly be forwarded and published. Summary balance sheets should be published more frequently (e.g., on a weekly or monthly basis).

Source: Lybek (1998 and 1999). 


\section{Central Bank Laws Covered In The Survey}

\begin{tabular}{|c|c|}
\hline Country & Name of the Law \\
\hline Angola & Law of the National Bank of Angola of April 23, 1997 \\
\hline Argentina & $\begin{array}{l}\text { Charter of the Central Bank of the Argentine Republic, Law 24,144 of September 23, 1992, } \\
\text { amended as of September } 2003 \text { (Law 25,780) }\end{array}$ \\
\hline Armenia & Law on the Central Bank of Armenia of June 30,1996 \\
\hline Australia & Reserve Bank Act, Act No. 4 of 1959 as amended on July 11, 2002 \\
\hline Austria $^{2 /}$ & Federal Act on the Oesterreichische National Bank (Austria), amended as of April 1, 2002 \\
\hline Bahamas & $\begin{array}{l}\text { An Act to Repeal the Central Bank of the Bahamas Act and to make fresh provisions for the } \\
\text { establishment of a central bank, its functions and duties; and for connected purposes, date of } \\
\text { assent-29th December, 2000 }\end{array}$ \\
\hline Bahrain $^{5 /}$ & Bahrain Monetary Agency Law_-Decree Law No. (23) of 1973, amended as of July 1981 \\
\hline Barbados & $\begin{array}{l}\text { Chapter 323C. Central Bank of Barbados [An Act to provide for the establishment of a } \\
\text { Central Bank of Barbados and for related matters] } 1992\end{array}$ \\
\hline Belgium $^{2 /}$ & $\begin{array}{l}\text { Organic Law of the National Bank of Belgium of February 22, 1998, last amendment- } \\
\text { April 24, } 1998\end{array}$ \\
\hline Bolivia & Law on the Central Bank of Bolivia, Law 1670 of October 31, 1995 \\
\hline $\begin{array}{l}\text { Bosnia and } \\
\text { Herzegovina }\end{array}$ & $\begin{array}{l}\text { Law of Bosnia and Herzegovina on the Central Bank of Bosnia and Herzegovina, amended } \\
\text { as of March 7, } 2003\end{array}$ \\
\hline Botswana & Bank of Botswana Act No. 19/1996, last amendment: Act No. 19/1999 \\
\hline Brazil $^{1 /}$ & $\begin{array}{l}\text { Central Bank Law of Brazil, Law No. 4595/64 of December 31, 1964, amended as of May } \\
31,2000\end{array}$ \\
\hline Bulgaria & Law on the Bulgarian National Bank, amended as of 2002 \\
\hline Cambodia & $\begin{array}{l}\text { Law on the Organization and Functioning of the National Bank of Cambodia of January 26, } \\
1996\end{array}$ \\
\hline Canada & Bank of Canada Act, R. S. 1985, with amendments to 2001 \\
\hline Cape Verde & Republic of Cape Verde the National Assembly, Law No. 10/V/2002 \\
\hline $\begin{array}{l}\text { Central African } \\
\text { States }^{3 /}\end{array}$ & Statutes of the Bank of Central African States \\
\hline Chile & $\begin{array}{l}\text { Law 18,840, Basic Constitutional Act of the Central Bank of Chile, amended as of May 31, } \\
2002\end{array}$ \\
\hline China, P.R. & Law on the People's Republic of China on the People's Bank of China of March 18, 1995 \\
\hline Colombia & $\begin{array}{l}\text { Law No. } 31 \text { of December 29, } 1992 \text { [on the bank of the Republic of Colombia], amended as } \\
\text { of December 29, } 1992\end{array}$ \\
\hline Croatia & Law on the Croatian National Bank, new law enacted on April 5, 2001 \\
\hline Cyprus & The Central Bank of Cyprus Law of 2002 (N. 138(I) 2002) \\
\hline Czech Republic & $\begin{array}{l}\text { Czech National Council Act No. 6/1993 Coll of } 17 \text { December } 1992 \text { on The Czech National } \\
\text { Bank, with amendments as of May 1, } 2002\end{array}$ \\
\hline El Salvador & Charter of the Central Reserve Bank of El Salvador, Reforms of May 23, 1996 \\
\hline Eritrea & Bank of Eritrea Proclamation, No. 93 of 1997 \\
\hline Estonia & $\begin{array}{l}\text { Law on the Central Bank of the Republic of Estonia of } 18 \text { May 1993, last amendment—RT I } \\
1999,16,271\end{array}$ \\
\hline $\begin{array}{l}\text { European } \\
\text { Economic and } \\
\text { Monetary Union }\end{array}$ & $\begin{array}{l}\text { Protocol on the Statute of the European System of Central Banks and of the European } \\
\text { Central Bank }\end{array}$ \\
\hline Fiji & $\begin{array}{l}\text { Chapter 210: Reserve Bank of Fiji. An Act to Establish the Reserve Bank of Fiji as } \\
\text { Successor to the Central Monetary Authority of Fiji and for the Purposes Connected } \\
\text { therewith of January 1, 1984, amended as of } 1998\end{array}$ \\
\hline Finland $^{2 /}$ & Act on the Bank of Finland, No. 214/1998 of 27 March 1998 \\
\hline France $^{2 /}$ & $\begin{array}{l}\text { Statute of the Banque de France, last amendment - Act 98-357 of } 12 \text { May 1998, amended } \\
\text { as of Sept. 17, } 2000\end{array}$ \\
\hline Georgia & The Organic Law of Georgia on the National Bank, as amended - October 23,2001 \\
\hline Germany $^{2 /}$ & Bundesbank Act, amended as of March 2002 \\
\hline
\end{tabular}




\begin{tabular}{|c|c|}
\hline Country & Name of the Law \\
\hline Guatemala & Organic Law of the Bank of Guatemala, Decree 16/2002 of April 23, 2002 \\
\hline Honduras & Central Bank of Honduras Law, amended as of January 2002 \\
\hline Hungary & Act LVIII of 2001 on the National Bank of Hungary \\
\hline Iceland & Act on the Central Bank of Iceland, amended as of May 2001 \\
\hline Italy $^{2 /}$ & Statute of the Bank of Italy of June 11, 1936, amended as of April 24, 1998 \\
\hline Jamaica & Bank of Jamaica Act No. 32 of 1960, amended as of 2001 \\
\hline Japan & The Bank of Japan Law of June 11, 1997, last amendment - January 6, 2001 \\
\hline Jordan & Central Bank of Jordan, Law No. 23 of the year 1971, amended as of 1992. \\
\hline Kazakhstan & $\begin{array}{l}\text { Law on the National Bank of the Republic of Kazakhstan of March 30,1999, amended as of } \\
\text { August } 7,1999\end{array}$ \\
\hline Kenya & The Central Bank of Kenya Act of 1966, amended as of January 1, 2001 \\
\hline Korea & $\begin{array}{l}\text { The Bank of Korea Act, Law No. } 138 \text { of May 5, 1950, last amendment—Law No. } 5491 \text { of } \\
\text { December 31, } 1997\end{array}$ \\
\hline Kuwait $^{5 /}$ & $\begin{array}{l}\text { Law No. 32/1968 Concerning Currency, the Central Bank of Kuwait and the Organization of } \\
\text { Banking Business }\end{array}$ \\
\hline Kyrgyz Republic & $\begin{array}{l}\text { Law of the Kyrgyz Republic on the National Bank of the Kyrgyz Republic of August 6, } \\
1997\end{array}$ \\
\hline Lao P.D.R. & $\begin{array}{l}\text { The Bank of the Lao P.D.R. - Law No. } 5 \text { dated October 14, 1994, amended as of October } \\
20,1999\end{array}$ \\
\hline Latvia & Law "On the Bank of Latvia" of May 19, 1992, amended as of July 12, 2002 \\
\hline Lesotho & Central Bank of Lesotho Bill 2000 \\
\hline Liberia & An Act to Authorize the Establishment of the Central Bank of Liberia of March 18, 1999 \\
\hline Lithuania & $\begin{array}{l}\text { Law on the Bank of Lithuania, Law No. I-678 of December 1, 1994, last amendment - March } \\
13,2001\end{array}$ \\
\hline Macedonia FRY & Law on the National Bank of the Republic of Macedonia of 1992, amended as of 2002 \\
\hline Madagascar & Charter of the Central Bank of Madagascar, Law No. 94-04 of June 10, 1994 \\
\hline Malawi & Reserve Bank of Malawi Act, Laws of Malawi Chapter 44:02 adopted in 1989 \\
\hline Malaysia & Central Bank of Malaysia Act 1958 (ACT 519), Revised up to March 31, 1994 \\
\hline Moldova & Law on the National Bank of Moldova of July 27, 1995, amended as of October 27, 2001 \\
\hline Morocco $^{1 /}$ & Statutes of Bank Al-Maghrib-Morocco of July 1, 1959, amended as of 1993 \\
\hline Mozambique & Law $1 / 92$ of January 3,1992 \\
\hline Namibia & Bank of Namibia Act, 1997 (Act No. 15 of 1997) \\
\hline Nepal & Nepal Rastra Bank Act of January 30, 2002 \\
\hline Netherlands ${ }^{2 /}$ & Bank Act 1998 [Edition 2000] \\
\hline New Zealand & Reserve Bank of New Zealand Act of 1989, amended as of 2003 \\
\hline Nicaragua & Organic Law of the Central Bank of Nicaragua, Law No. 317 of March 30, 2001 \\
\hline Nigeria & $\begin{array}{l}\text { Central Bank of Nigeria Decree No. } 24 \text { of } 1991 \text { with amendments as of Decree No. } 37 \text { of } \\
1998\end{array}$ \\
\hline Norway & $\begin{array}{l}\text { Act on Norges Bank and the Monetary System of May 24, 1985, amended as of December } \\
17,1999\end{array}$ \\
\hline $\mathrm{Oman}^{5 /}$ & Central Bank of Oman, Royal Decree No. 114/2000 of December 16, 2000 \\
\hline Pakistan & The State Bank of Pakistan Act of 1956, as amended by Ordinance of November 2002 \\
\hline Papua New Guinea & Central Banking Act of April 20,2000 \\
\hline Paraguay & Law No. 489 Organic Law of the Central Bank of Paraguay, amended as of 1997 \\
\hline Peru & Central Reserve Bank of Peru Organic Law, Decree-Law No. 26123 of January 1, 1993 \\
\hline Philippines & The New Central Bank Act of the Republic of Philippines of July, 1992 \\
\hline Poland & Law of August 29, 1997 on the National Bank of Poland, amended as of January $1,2003^{5 /}$ \\
\hline Portugal & Banco de Portugal Organic Law, amended as of April 17, 2001 \\
\hline Qatar $^{6 /}$ & $\begin{array}{l}\text { Decree Law No. } 15 \text { of the Year } 1993 \text { Establishing Qatar Central Bank s amended by the Law } \\
\text { No. } 19 \text { of the Year } 1997\end{array}$ \\
\hline Romania & $\begin{array}{l}\text { Law on the Statute of the National Bank of Romania of May 26, 1998, last amendment- } \\
\text { Law No. } 156 \text { of October } 12,1999\end{array}$ \\
\hline
\end{tabular}




\begin{tabular}{|c|c|}
\hline Country & Name of the Law \\
\hline Russia & $\begin{array}{l}\text { Federal Law No. 86-FZ on the Central Bank of the Russian Federation (The Bank of Russia) } \\
\text { of June 27, } 2002\end{array}$ \\
\hline Rwanda & Law No 11/97 of 26/7/1997—regarding Statutes of the National Bank of Rwanda \\
\hline Serbia & Law on the National Bank of Serbia of 2003 \\
\hline Sierra Leone & The Bank of Sierra Leone Act of February 28, 2000 \\
\hline Singapore & Monetary Authority of Singapore Act, Chapter 186, last amendment-Coctober 8, 1999 \\
\hline Slovenia & Bank of Slovenia Act of July 2002 \\
\hline South Africa & South African Reserve Bank Act of August 1, 1989, amended as of 2000 \\
\hline Spain $^{2 /}$ & $\begin{array}{l}\text { Law of Autonomy of the Banco de Espana, Law 13/1994 of June 1, amended by Law } 12 \text { of } \\
\text { April } 28,1998\end{array}$ \\
\hline Sudan & The Bank of Sudan Act, 2002 \\
\hline Sweden & The Sveriges Riksbank Act (1988:1385)—as of June 1, 2001 \\
\hline Switzerland & National Bank Law (NBL) of December 231953 (as of May 1, 2000) \\
\hline Tajikistan & $\begin{array}{l}\text { Law of the Republic of Tajikistan on the National Bank of the Republic of Tajikistan, } \\
\text { amended as of December } 14,1996\end{array}$ \\
\hline Tanzania & Bank of Tanzania Act of February 17, 1995 \\
\hline $\begin{array}{l}\text { Trinidad and } \\
\text { Tobago }\end{array}$ & Central Bank Act—Chapter 79:02, amended as of 1994 \\
\hline Tunisia & $\begin{array}{l}\text { Law } 58-90 \text { of September 19, 1958, establishing and Organizing the Central Bank of Tunisia, } \\
\text { amended as of April 4, 2000 }\end{array}$ \\
\hline Turkey & $\begin{array}{l}\text { The Law on the Central Bank of the Republic of Turkey (Law No. 1211), amended as of } \\
\text { April 25, } 2001\end{array}$ \\
\hline Turkmenistan & $\begin{array}{l}\text { Law on the Central Bank of Turkmenistan of October 8, 1993, amended as of September 23, } \\
1994\end{array}$ \\
\hline Ukraine & Law of Ukraine on the National Bank of Ukraine, as of May 20, 1999 \\
\hline $\begin{array}{l}\text { United Arab } \\
\text { Emirates }^{6 /}\end{array}$ & $\begin{array}{l}\text { Union Law No. } 10 \text { Concerning the Central Bank, the Monetary System and Organization of } \\
\text { Banking of August } 1980\end{array}$ \\
\hline United Kingdom & Bank of England Act of April 23, 1998 with amendments until 2001. \\
\hline United States & Chapter 3-Federal Reserve System of December 23, 1913 \\
\hline Uzbekistan & $\begin{array}{l}\text { Law of the Republic of Uzbekistan "On the Central Bank of the Republic of Uzbekistan" No. } \\
\text { 154-I Dated 12/21/95, amended as of December 15, } 2000\end{array}$ \\
\hline Venezuela & "Law on the Central Bank of Venezuela", amended as of September 4, 2001 \\
\hline $\begin{array}{l}\text { West African } \\
\text { States }{ }^{4 /}\end{array}$ & $\begin{array}{l}\text { Statutes of the Central Bank of West African States of November 2, 1962, amended as of } \\
\text { November } 14,1973\end{array}$ \\
\hline Yemen & Law on the Central Bank of Yemen, June 25, 2000 \\
\hline Zambia & The Bank of Zambia Act, Act No. 43 of 1996 of December 12, 1996 \\
\hline \multicolumn{2}{|c|}{$\begin{array}{l}\text { 1/ Currently in the process of amending the central bank law. } \\
\text { 2/ The members of the European Monetary System-defined as the European Central Bank plus the national } \\
\text { central banks that have adopted the euro-include: Austria, Belgium, Germany, Greece, Spain, Finland, France, } \\
\text { Ireland, Italy, Luxembourg, Netherlands, and Portugal. } \\
\text { 3/ Members of Central Africa Monetary Union include: Cameroon, Central African Republic, Chad, Congo, } \\
\text { Equatorial Guinea, and Gabon. } \\
\text { 4/ Members of West African Monetary Union include: Benin, Burkina Faso, Cote d'Ivoire, Guinea Bissau, Mali, } \\
\text { Niger, Senegal and Togo. } \\
\text { 5/ The Act on the National Bank of Poland was amended on December 18, 2003, which entered into effect on } \\
\text { January 1, 2004. The most recent amendment of the Act was adopted on April 20, } 2004 \text {. } \\
\text { 6/ Member of the Cooperation Council of the Arab States of the Gulf (GCC). GCC members include: Bahrain, } \\
\text { Kuwait, Oman, Qatar, Saudi Arabia, and United Arab Emirates. }\end{array}$} \\
\hline
\end{tabular}

